\title{
Validation of microarray data in human lymphoblasts shows a role of the ubiquitin- proteasome system and NF-kB in the pathogenesis of Down syndrome
}

\author{
Barbara Granese ${ }^{1+}$, Iris Scala ${ }^{1+}$, Carmen Spatuzza², Anna Valentino ${ }^{1}$, Marcella Coletta', Rosa Anna Vacca ${ }^{3}$,
} Pasquale De Luca ${ }^{4}$ and Generoso Andria ${ }^{1 *}$

\begin{abstract}
Background: Down syndrome (DS) is a complex disorder caused by the trisomy of either the entire, or a critical region of chromosome 21 (21q22.1-22.3). Despite representing the most common cause of mental retardation, the molecular bases of the syndrome are still largely unknown.

Methods: To better understand the pathogenesis of DS, we analyzed the genome-wide transcription profiles of lymphoblastoid cell lines (LCLs) from six DS and six euploid individuals and investigated differential gene expression and pathway deregulation associated with trisomy 21. Connectivity map and PASS-assisted exploration were used to identify compounds whose molecular signatures counteracted those of DS lymphoblasts and to predict their therapeutic potential. An experimental validation in DS LCLs and fetal fibroblasts was performed for the most deregulated GO categories, i.e. the ubiquitin mediated proteolysis and the NF-kB cascade.

Results: We show, for the first time, that the level of protein ubiquitination is reduced in human DS cell lines and that proteasome activity is increased in both basal conditions and oxidative microenvironment. We also provide the first evidence that NF-kB transcription levels, a paradigm of gene expression control by ubiquitin-mediated degradation, is impaired in DS due to reduced IkB-alfa ubiquitination, increased NF-kB inhibitor (IKB-alfa) and reduced p65 nuclear fraction. Finally, the DSCR1/DYRK1A/NFAT genes were analysed. In human DS LCLS, we confirmed the presence of increased protein levels of DSCR1 and DYRK1A, and showed that the levels of the transcription factor NFATc2 were decreased in DS along with a reduction of its nuclear translocation upon induction of calcium fluxes.
\end{abstract}

Conclusions: The present work offers new perspectives to better understand the pathogenesis of DS and suggests a rationale for innovative approaches to treat some pathological conditions associated to DS.

Keywords: Down syndrome, Trisomy 21, Expression, Ubiquitin-proteasome system, NF-kB

\section{Background}

Down syndrome (DS) (MIM 190685) is a human complex disorder caused by the trisomy of either the entire, or a critical region of chromosome (chr) 21 (21q22.1-22.3). DS phenotypes are often variable. Intellectual disability and hypotonia are the hallmarks of the syndrome, while a

\footnotetext{
*Correspondence: andria@unina.it

${ }^{\dagger}$ Equal contributors

'Department of Pediatrics, Federico II University, Naples 80131, Italy

Full list of author information is available at the end of the article
}

wealth of distinct clinical manifestations, including congenital malformations, increased incidence of cancer, immune and endocrine abnormalities occur only in subsets of DS subjects. DS is also characterized by premature aging and dementia with neurological features that mimic those found in Alzheimer's disease. The underlying molecular mechanisms of DS are largely unknown. Several genome-wide expression studies have been performed both in mouse and human trisomic tissues. While DS mice models have unravelled a generalized overexpression of triplicated genes [1-4], the analysis of human DS tissues 
showed contradictory results. In fact, some studies reported the selective over-expression of a limited subset of chr 21 genes [5-9], and others described subtle upregulations of chr 21 genes associated to a secondary, generalized and more extreme transcriptional deregulation of genes mapping on other chromosomes [10-15]. An additional level of complexity comes from the observation that gene expression differs extensively among unaffected individuals [16-19], including the expression of a number of chr 21 genes [20,21]. Therefore, some authors suggested to regard as poor candidates for DS pathogenesis those genes with high expression variation among controls and as reliable candidates those genes over-expressed in DS and tightly regulated in euploid cells [21-23]. Gene expression studies failed to provide definitive results; however, evidence in human DS cells point to the presence of abnormalities of extracellular matrix, of mitochondrial function and other metabolic pathways, including purine metabolism, in fetal specimens [5,11,13], and changes in transcriptional regulation, oxidative stress and immunerelated genes in adult tissues $[6,12,14,24,25]$. Recently, the effect of single chr 21 genes on the trisomic trancriptome was established by comparing the genome-wide expression from mouse ES cells, engineered to host the whole human chr 21, with those overexpressing only single chr 21 genes. A subset of genes, including Runx1, Erg, Nrip, Olig2, PdxK and Aire, produced the strongest transcriptional response when overexpressed [26]. More recently, Vilardell et al. [27] performed a meta-analysis from 45 publicly available DS data sets, from both human and mouse transcriptome and proteome. The identified biological functions were mainly related to nervous system development, neurodegenerative disorders (e.g. Huntington's disease, Alzheimer's disease and Parkinson's disease) and defects in synapsis function (e.g. axon guidance, NGF signalling). Seventy distinct transcription factors, including RelA, NFATc1, NFATc2 and NFATc3, were identified as being affected by dosage imbalance.

Besides genome-wide expression analysis, few studies attempted to identify selected gene networks associated to specific DS features and to characterize molecular and biochemical functions disrupted in DS. In mice, Arron et al. [28] found that two critical chr 21 genes (DYRK1A and DSCR1, also known as RCAN1) act synergistically to control the nuclear localization of NFAT family of transcription factors and that knock-out mice for NFATc1, NFATc2, NFATc3 and NFATc4 display cardiovascular, neurological, skeletal and immune phenotypes strikingly similar to DS. In addition, DSCR1 promotes neurotoxicity [29] and attenuates the inflammatory response by stabilizing $\mathrm{I} k \mathrm{~B}$-alfa [30]. The extra copy of DYRK1A in DS has been also associated to early onset of Alzheimer's disease [31] and to defective neuronal development mediated by the reduction of REST, a key regulator of pluripotency and neuronal differentiation [32]. DSCR1/NFAT pathway was also associated with neuronal susceptibility to oxidative stress [33], a biochemical feature of DS. Finally, a limited number of functional studies in human DS cells have unravelled a disruption of mitochondrial function as a pathogenetic trigger [34-37].

In this study we analyzed the genome-wide transcription profile of lymphoblastoid cell lines (LCLs) from DS and control subjects to investigate differential gene expression and pathway deregulation associated with trisomy 21 . This cellular model has been widely used to analyze the expression profiles of chr 21 genes [21,23,38] as well as of other diseases including cancer [39-41] and neurodegenerative disorders [42,43]. Diseased versus control and intra-group comparisons were used to analyze the gene expression levels of chr 21 genes. The experimental validation focused on the most deregulated gene ontology (GO) categories to confirm their imbalance in DS, i.e. the ubiquitin mediated proteolysis and the NF- $k B$ cascade. Interestingly, these two celullar processes are closely interconnected since I $k \mathrm{~B}$-alfa, the key modulator of NF- $k \mathrm{~B}$, can be regarded as a model protein of regulation of signal transduction by the ubiquitinproteasome system (UPS). Moreover, both the ubiquitin mediated proteolysis and the $\mathrm{I} k \mathrm{~B} / \mathrm{NF}-\mathrm{kB}$ signal transduction interact with and regulate DSCR1 [44]. In mice, DSCR1 and DYRK1A act synergistically to prevent the nuclear occupancy of NFAT [28], a family of transcription factors activated by calcium fluxes. Finally, DSCR1 is ubiquitinated and degraded by both the proteasome and the autophagy-lysosome pathways [45]. As these pathways are interconnected and individually can cause immune response derangement, neurodegenerative diseases, premature aging and delay of cell growth, all main features of DS, our experimental validation focused on UPS, NF- $k$ B and DYRK1A/ DSCR1/NFAT genes. In human LCLs and fetal fibroblasts, we provide the first evidence that the level of protein ubiquitination is reduced in DS and that proteasome activity is increased in both basal conditions and oxidative microenvironment. In addition, we first show that the NF- $k B$ transcriptional activity is impaired in DS due to reduced $\mathrm{I} k \mathrm{~B}$-alfa ubiquitination, increased NF- $k \mathrm{~B}$ inhibitor ( $k \mathrm{~B}-\mathrm{B}$-alfa) cytosolic levels and reduced p65 nuclear fraction. Finally, the investigation of DSCR1/DYRK1A/NFAT genes, linked to the pathogenesis of DS in animal studies, confirmed increased protein levels of DSCR1 and DYRK1A and showed reduced levels of NFATc2 and decreased NFATc2 nuclear translocation upon calcium flows induction, adding new evidence to a transcriptional regulation deficit in DS. 


\section{Methods}

\section{Cell culture}

LCLs were generated from peripheral blood samples of six karyotypically confirmed full trisomy 21 children and six age-matched controls ( $5 \pm 1$ year-old) recruited at the Department of Pediatrics, Federico II University of Naples. The study was performed in accordance with the principles of the Helsinki Declaration and was approved by the Federico II University Ethics Committee 'Carlo Romano'. The parents of all subjects gave written informed consent before participation. Lymphocytes were isolated by ficollhypaque (Gibco) and resuspended in 17\% FBS-RPMI1640 and equal volume of supernatant from overgrown B95.8 cell cultures in presence of $10 \mu \mathrm{g} / \mathrm{ml}$ of cyclosporine (Sandimmune Oral Suspension). Cells were grown in 17\% FBS-RPMI-1640 (Cambrex) supplemented with $5000 \mathrm{U} / \mathrm{ml}$ penicillin-streptomycin, $2 \mathrm{mM}$ glutamine (Gibco) and $0.16 \mathrm{mg} / \mathrm{ml}$ gentamicin, in a $37^{\circ} \mathrm{C}, 5 \% \mathrm{CO}_{2}$ incubator.

Fibroblasts from two DS and two control fetuses, spontaneously aborted at a gestational age between 14 and 19 weeks, were obtained from the Galliera Genetic Bank (Galliera Hospitals, Genova, Italy) in agreement with ethical guidelines stated in the TGB Network Charter and upon written informed consent. Cells were cultured at $37^{\circ} \mathrm{C}$ in D-MEM medium (Gibco) supplemented with $17 \% \mathrm{FBS}, 5000 \mathrm{U} / \mathrm{ml}$ penicillin-streptomycin, $2 \mathrm{mM}$ glutamine (Gibco), in a $37^{\circ} \mathrm{C}, 5 \% \mathrm{CO}_{2}$ incubator. For functional analyses, sub-confluent cultures with comparable number of culture passages (5-15) and growth rate were used. Each aliquot of LCLs was maintained in culture for no longer than 3 months (less than 160 'population doubling levels') [46]. To exclude the possibility of chromosomal rearrangements (other than full trisomy 21) during culturing, LCLs were karyotyped before microarray analysis and before each experimental validation.

\section{Cell treatment}

Calcium flows were induced with $10 \mathrm{ng} / \mathrm{ml}$ PMA and $1 \mathrm{mg} / \mathrm{ml}$ Ionomycin (Sigma) for 4 hours at $37^{\circ} \mathrm{C}$. For the proteasome blocking, cells were treated with $40 \mu \mathrm{M}$ MG132 (Calbiochem) for 6 hours at $37^{\circ} \mathrm{C}$ for western blot experiments and $100 \mu \mathrm{M}$ MG-132 for 2 hours for proteasome assay. Oxidative stress was induced with $0.1 \mathrm{mM}$ $\mathrm{H}_{2} \mathrm{O}_{2}$ for 30 minutes and recoveries were observed 1, 2 and 4 hours after cell refreshing with RPMI without $\mathrm{H}_{2} \mathrm{O}_{2}$. Phospho-IkB-alfa was analyzed after cell treatment with $40 \mu \mathrm{M}$ MG132 for 30 minutes and incubation with $0.3 \mu \mathrm{M}$ Calyculin A for an additional 30 minutes [47].

\section{RNA extraction and microarray hybridization procedure}

RNAs from six DS and six control LCLs were independently hybridized on the Affymetrix HU133 plus 2.0 oligonucleotide array (Affymetrix, Santa Clara, CA), which allows the analysis of over 47,000 human transcripts including 38,500 well-characterized human genes. Total RNAs were obtained using TRIzol reagent (Gibco/ BRL Life Technologies, Inc., Gaithersburg, MD) and used to prepare biotinylated target cRNA, according to the Affymetrix procedures. Quality and amount of starting RNA were confirmed using spectrophotometry and agarose gel electrophoresis. Purification of PolyA + mRNA from total RNA was performed with the Oligotex mRNA Kit (QIAGEN GmbH, Hilden, Germany): $1 \mu \mathrm{g}$ of mRNA was used to generate first-strand cDNA by using a T7-linked oligo(dT) primer; after second strand synthesis, in-vitro transcription was performed with biotinylated UTP and CTP using the Enzo BioArray High Yield RNA Transcript Labeling Kit (Enzo Diagnostics, Farmingdale, NY). The target cRNA generated from each sample was processed according to the manufacturer's procedures. Fragmentation of biotinylated cRNA, washing and staining were done according to the instructions provided by Affymetrix.

\section{Experimental design}

The experimental design was a diseased versus control comparison. To assess the expression variation of chr 21 genes among DS and control samples, we focused our analysis on the variability of all chr 21 transcripts present on the array with $\mathrm{FC} \geq 1.2(\mathrm{n}=167)$, irrespective of the statistical analysis that excludes 'a priori' variable genes. Gene variability was assessed by the $\mathrm{CV}$, calculated as the ratio between standard deviation and mean expression levels for each gene among samples [22]. Arbitrary cut-offs were set at 0.2 and 0.5 and transcripts were divided into three classes: $\mathrm{CV} \leq 0.2$, corresponding to the tightly regulated genes; $0.2<\mathrm{CV}<0.5$, corresponding to genes with little variation; $C V \geq 0.5$, corresponding to highly variable genes.

\section{Data acquisition and processing}

After scanning, array images were assessed by eye to confirm scanner alignment and the absence of significant bubbles or scratches on the chip surface. 3'/5' ratios for GAPDH and beta-actin were confirmed to be within acceptable limits (0.70-1.64), and BioB spike controls were found to be present on all chips, with BioC, BioD and CreX also present in increasing intensity. Array scanning data (CEL files) were processed using the RMA algorithm [48]. GeneSpring software (Silicon Genetics, Redwood City, CA) was used for data mining. Raw expression data were normalized per gene by dividing each measurement for each gene by the median of that gene's measurements in the corresponding control non-trisomic samples. Normalized data were log-transformed. To reduce the noise and the variability induced by several 
sources including the manufacturing processes and the experimental procedures [49], expression data were pre-filtered and genes were considered suitable for differential evaluation if called present in at least 4 out of 6 samples. Microarray data were submitted to ArrayExpress (http://www.ebi.ac.uk/arrayexpress/) database (accession n. E-MTAB-1238). Statistical evaluation was performed by Welch t-test, corrected with Benjamini-Hochberg FDR algorithm and filtered for fold-changes in DS vs controls $\geq$ 1.2. Statistical significance was assessed at 0.05 and, for a further analysis, at 0.01 . Supervised classification of samples was performed using hierarchical clustering (GeneSpring software).

\section{Bioinformatics data analyses}

GO and pathway analyses of gene lists were performed using David Bioinformatics software (http://david.abcc. ncifcrf.gov/) [50]. For GO functional class scoring, a modified Fisher exact test (EASE score) was used and the statistical significance was set at $\mathrm{p}$-value $<0.05$. The fold enrichment (FE) value was used as a measure of the magnitude of enrichment. To compare results and to highlight more reliable GO classes, a second web-based software was used, the Gene Ontology Tree Machine (GOTM) [51]. To identify compounds with molecular signatures that might mitigate the effects of trisomy 21 , Connectivity Map build 0.2 was used. The database contains 564 expression profiles representing the effects of 164 compounds on 4 cancer cell lines, using the Affymetrix U133 microarrays [52]. Because the U133 plus 2.0 array contains a greater number of probe-sets, the Connectivity Map analysis was performed using only the probe-sets common to both arrays. A list of perturbagens, hypothetically connected (positively and negatively) with the signature of interest was generated according to the permutation p. Perturbagenes with negative enrichment scores $(<-0.7)$ were considered connected to the reversal or repression of the biological state encoded in the query signature. Perturbagens with enrichment scores $<-0.7$ and $p$-value $<0.05$ were entered in the PASSonline software (Prediction of Activity Spectra for Substances) $[53,54]$ in order to estimate their predicted activity. The current version of PASS available online (http://www.pharmaexpert.ru/passonline/index.php) predicts around 3750 pharmacological effects, biochemical mechanisms of action, specific toxicities and metabolic terms on the basis of structural formulae of drug-like substances with average accuracy $\sim 95 \%$. The predicted activity spectrum of a compound is estimated as probable activity (Pa) and probable inactivity $(\mathrm{Pi})$ and only activities with $\mathrm{Pa}>\mathrm{Pi}$ are considered. When $\mathrm{Pa}>0.7$, there is a high chance to confirm the activity experimentally, while if $0.5<\mathrm{Pa}<0.7$, the probability is lower but there is more than $50 \%$ chance for the compound to be a novel therapeutic molecule. Only compounds with $\mathrm{Pa}>0.5$ were considered here as potential therapeutic molecules.

\section{Quantitative Real-Time PCR}

Single stranded cDNA was synthesized with random hexamer primers starting from $2 \mu \mathrm{g}$ of total RNA using the High Capacity cDNA Archive Kit (Applied Biosystems). Real-time PCR was performed using $2 \mu \mathrm{l}$ of $\mathrm{cDNA}$ and TaqMan Universal PCR MasterMix 2X on the Applied Biosystems 7300, according to the manufacturer's procedures. PCR reactions were performed in triplicate. Beta-2-microglobulin and ring finger protein 111 (RNF111) housekeeping genes were chosen as reference genes $[55,56]$.

\section{Protein extraction}

Total protein extraction was carried out by cell incubation with the Tropix lysis solution (Applied Biosystems) supplemented with $0.1 \mathrm{M} \mathrm{DTT}$ in the presence of protease inhibitor cocktail 1X (Sigma). To better visualize protein-linked ubiquitins, lysis solution was supplemented with $5 \mathrm{mM}$ manganese and $50 \mu \mathrm{M}$ MG132 according to Mimnaugh and Neckers [57]. Cytoplasmic and nuclear fractions were obtained by celLytic NucLEAR Extraction kit (Sigma).

\section{Immunoprecipitation}

Immunoprecipitation was carried out incubating $500 \mu \mathrm{g}-$ $1 \mathrm{mg}$ cytoplasmic extracts with specific antibodies at $4^{\circ} \mathrm{C}$ for 2 hours. Dynabeads Protein G (Invitrogen) were added to the mixture and the incubation was continued for other 2 hours. Proteins complexed with antibody - Dynabeads Protein G were immunoprecipitated and washed for three times with the use of a magnet, and finally eluted by boiling in SDS sample buffer for 10 minutes.

\section{Western blot analysis}

Protein extracts $(25-45 \mu \mathrm{g})$ were separated by $7-10 \%$ SDS-PAGE and then transferred on PVDF membrane (Millipore). Membranes were then blocked for 1 hour in 5\% milk-1X PBS-0.1\% Tween-20 (T-PBS) and then incubated from 4 hours to overnight with dilutions of specific primary antibodies: 1:1000 anti-NFATc1 (H-110), 1:100 anti-NFATc2 (4G6-G5), 1:1000 anti-NFATc3 (M-75), 1:1000 anti-NFATc4 (H-74), 1:2500 anti-DYRK1A (H-143) (SantaCruz); 1:1000 anti-DSCR1 (N-20) (SIGMA); 1:2000 anti-NF-kB p65 (Upstate); 1:1000 anti-NF-kB p50 (Upstate); 1:1500 anti-I kB-alfa (L35A5), 1:1000 anti-pI kB-alfa (Ser32/36), 1:1000 anti-ubiquitin (P4D1) (CellSignaling). 1:2000 anti- $\alpha$-Tubulin (SIGMA) and 1:1000 Histone H1 (SPM 256) (SantaCruz) were used to normalize the levels of total, cytosolic and nuclear proteins. As secondary antibodies, 1:5000 anti-mouse, 1:2000 anti-rabbit and 1:2000 anti-goat IgG horseradish peroxidase conjugated 
(GE-Healthcare) were used and the specific bands were visualized by ECL plus reaction (GE-Healthcare).

\section{Luciferase assay}

To test NF- $k$ B transcriptional activity, LCLs from DS subjects and controls were plated in 24-well plates at density of $5 \times 10^{5}$ cells/well and transfected, 24 hours later, with pNF- $k$ B-Luc (Path Detect NF- $k$ B Cis-Reporting System, Stratagene) and pSV- $\beta$-Gal plasmid by using Turbofect Transfection Reagent (Fermentas), according to the manufacturer's instruction. Forty-eight hours posttransfection, cells were harvested and processed to evaluate the luciferase and $\beta$-galactosidase activities by using Dual Light Luciferase System (Tropix, Bedford, $\mathrm{MA}$, USA) in a bioluminometer (TECAN, Infinite 200). Experiments were performed in triplicate and repeated independently twice. The ratio of firefly luciferase activity to $\beta$-galactosidase activity was expressed as relative light units (RLU).

\section{Luminescent proteasome assay}

To individually measure the chymotrypsin-, trypsin- and caspase-like proteasome activities in cultured cells, the Proteasome-Glo ${ }^{\mathrm{TM}} 3$ substrates Cell-Based Assay (Promega) was used. LCLs were plated in 96-well plates at concentration of $2 \times 10^{4} /$ well and incubated at $37^{\circ} \mathrm{C}$ overnight. The day after, cells were treated with $100 \mu \mathrm{M}$ MG132 for 2 hours (inhibitor control) and $0.1 \mathrm{mM} \mathrm{H}_{2} \mathrm{O}_{2}$ for $30 \mathrm{mi}-$ nutes (test treatment) before adding the three specific proteasome substrates: Such-LLVY-Glow ${ }^{\text {тм }}$ Substrate for the Chymotrypsin-Like activity, Z-LRR-Glow ${ }^{\text {тм }}$ Substrate for the Trypsin-Like activity and Z-nLPnLD-Glo ${ }^{\mathrm{TM}}$ Substrate for the Caspase-Like activity. Luminescence for each sample, performed in duplicate and in two separate experiments, was read after 15 minutes in a plate-reading luminometer (TECAN, Infinite 200).

\section{Statistical analysis}

Data were reported as means \pm S.E. Statistical analysis was performed with SPSS 13.0 software and the student's t-test was used for the statistical significance (two-tailed, $\mathrm{p}<0.05$ ) of differences between means of DS and control subjects. To validate the microarray data, the average expression ratios (DS/controls) of both array and qRT-PCR were subjected to Pearson's correlation analysis.

\section{Results}

Supervised analysis of pooled data of DS and control samples

For the analysis of differentially expressed genes, six DS LCLs were compared to six control samples. A first list of 3,416 differentially expressed genes was generated by using a corrected p-value cut-off of 0.05. Of these, 1,051
(30.7\%) were up-regulated and 2,368 (69.3\%) were downregulated, with a gene expression variation ranging from 0.67 to 3.04. No chr 21 gene resulted down-regulated. A second list of genes was then generated by using a corrected p-value cut-off of 0.01 . In this case, a total of 406 transcripts resulted significantly either up-regulated $(\mathrm{n}=71 ; 17.5 \%)$ or down-regulated $(\mathrm{n}=335 ; 82.5 \%)$ (Additional file 1A). Supervised hierarchical clustering of both the 4,490 and the 406 transcripts clearly distinguished between DS and control samples (Additional file $1 B, C)$.

\section{Chr 21 expression profiles}

Two hundred-twenty genes out of 449 genes annotated on chr 21 (NCBI RefSeq 37.2) were detected in this microarray analysis. Among these, 59 known genes (13.1\% of total chr 21 annotated genes) resulted differentially expressed in DS vs controls ( $\mathrm{p}<0.05, \mathrm{FC} \geq 1.2$ ), with FC ranging from 1.20 to 2.57 and a mean DS/control ratio of $1.36 \pm 0.2$. A graphic view of the differentially expressed chr 21 genes is illustrated in Figure 1, that shows how a substantial number of triplicated genes escapes the genedosage rule. To identify functional categories associated with the trisomic genes, the list of chr 21 deregulated genes was submitted to a GO analysis. Results indicated 'ATPase activity coupled to transmembrane movement of substances' ( $\mathrm{p}=0.005$, FE 11.3), 'cofactor metabolic process' $(\mathrm{p}=0.029$, FE 5.8), 'regulation of cholesterol biosynthetic process' ( $\mathrm{p}=0.031, \mathrm{FE}$ 62.2) and 'oxidative phosphorylation' ( $\mathrm{p}=0.04, \mathrm{FE} 9.2$ ) as the major enriched categories (Table 1). The analysis of the same genes, performed using KEGG database, showed Parkinson's ( $p=0.01$, FE 8.3), Alzheimer's ( $p=0.02$, FE 6.1) and Huntington's ( $p=0.03$, FE 5.5) diseases as the most deregulated biological pathways (Table 2).

\section{Analysis of chr 21 gene expression variability among DS and controls}

To assess the expression variation of chr 21 genes among DS and control samples, we focused the analysis on the variability of all chr 21 transcripts present on the array with $\mathrm{FC} \geq 1.2(\mathrm{n}=167)$. Among controls, 77 transcripts (46.1\%) had $\mathrm{CV} \leq 0.2,74$ (44.3\%) had $0.2<\mathrm{CV}<$ 0.5 and $16(9,6 \%)$ had $C V \geq 0.5$. Among DS samples, 110 transcripts (65.9\%) had $\mathrm{CV} \leq 0.2,48(28.7 \%)$ had $0.2<$ $\mathrm{CV}<0.5$ and 9 (5.4\%) had $\mathrm{CV} \geq 0.5$ (Table 3). Fifty-five transcripts were tightly regulated in both DS and controls and among them, notably, mitochondrial-related genes (ATP5O, ATP5J and NDUFV3), SOD1, DYRK1A and cell-cycle related genes (Additional file 2). GO analysis of this gene subset revealed the enrichment of the following categories: 'Cofactor metabolic process' ( $\mathrm{p}=0.007$, FE 9.4), 'ATPase activity, coupled to movement of substances' ( $\mathrm{p}=0.0018 ; \mathrm{FE} 15.9)$, 'oxidative phosphorylation' 


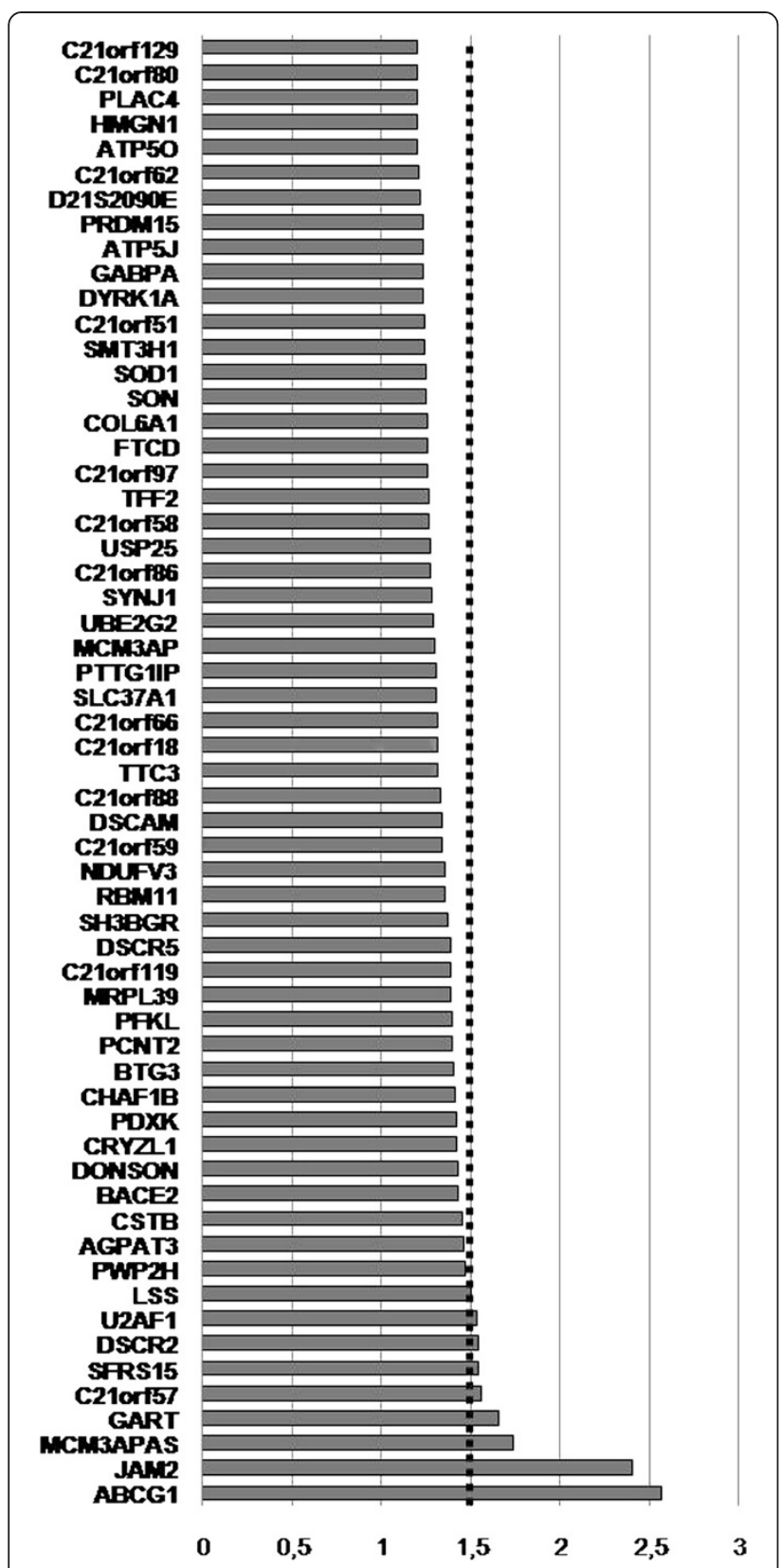

Figure 1 Average up-regulation ratios of chromosome 21 differentially expressed genes $(p<0.05)$.

( $\mathrm{p}=0.016, \mathrm{FE} 14.9)$, 'mitochondrial proton-transporting ATP synthase complex, coupling factor $F(o)$ ' ( $\mathrm{p}=0.016$, FE 120.4), 'regulation of cholesterol biosynthetic process' ( $\mathrm{p}=$ 0.019, FE 100.3) (Table 4). KEGG database showed the enrichment of 'oxidative phosphorylation' ( $\mathrm{p}=0.03$, FE 9.9) besides Parkinson's, Huntington's and Alzheimer's diseases (Table 5). Neither GO enriched categories nor KEGG pathways were associated to the 22 transcripts tightly regulated in controls $(\mathrm{CV} \leq 0.2)$ and with little variation in DS $(0.2<\mathrm{CV}<0.5)$.
Table 1 Enriched GO categories of chromosome 21 up-regulated genes

\begin{tabular}{|c|c|c|c|c|}
\hline GO term & Genes & $\% *$ & $\mathrm{p}$-value & FE \\
\hline \multirow{3}{*}{$\begin{array}{l}\text { ATPase activity, coupled to } \\
\text { transmembrane movement } \\
\text { of substances }\end{array}$} & ATP5O & \multirow[t]{3}{*}{6.2} & \multirow[t]{3}{*}{0.005} & \multirow[t]{3}{*}{11.3} \\
\hline & ATP5J & & & \\
\hline & ABCG1 & & & \\
\hline \multirow[t]{4}{*}{ Cofactor metabolic process } & SOD1 & \multirow[t]{4}{*}{6.2} & \multirow[t]{4}{*}{0.029} & \multirow[t]{4}{*}{5.8} \\
\hline & FTCD & & & \\
\hline & PDXK & & & \\
\hline & CRYZL1 & & & \\
\hline \multirow{2}{*}{$\begin{array}{l}\text { Regulation of cholesterol } \\
\text { biosynthetic process }\end{array}$} & $\mathrm{ABCG} 1$ & \multirow[t]{2}{*}{3.1} & \multirow[t]{2}{*}{0.031} & \multirow[t]{2}{*}{62.2} \\
\hline & SOD1 & & & \\
\hline \multirow[t]{3}{*}{ Oxidative phosphorylation } & ATP5O & \multirow[t]{3}{*}{4.7} & \multirow[t]{3}{*}{0.04} & \multirow[t]{3}{*}{9.2} \\
\hline & ATP5J & & & \\
\hline & NDUFV3 & & & \\
\hline
\end{tabular}

FE fold enrichment, $* \%$ of genes in category.

Genome-wide expression analysis, functional classes and pathway perturbation

GO functional class scoring was performed by comparing the list of the 406 differentially expressed genes to the complete list of genes spotted on the array.

Our analysis revealed a down-regulation of the biological processes related to ubiquitin metabolism; cell signalling, with a particular enrichment for the NF- $k$ B cascade; cell cycle; protein localization; regulation of gene expression (Table 6). Among up-regulated categories, the most disrupted were those related to developmental processes and to transport and localization, with a strong enrichment of calcium ion transport (Table 7).

Table 2 Enriched pathways of chromosome 21 up-regulated genes

\begin{tabular}{ccccc}
\hline Pathway term & Genes & $\%$ & p-value & FE \\
\hline Parkinson's disease & ATP5O & 6.2 & 0.010 & 8.3 \\
& ATP5J & & & \\
& NDUFV3 & & & \\
& UBC6/7 & & & \\
Alzheimer's disease & ATP5O & 6.2 & 0.023 & 6.1 \\
& ATP5J & & & \\
& NDUFV3 & & & \\
Huntington's disease & BACE & & & \\
& ATP5O & 6.2 & 0.030 & 5.5 \\
& ATP5J & & & \\
\hline & NDUFV3 & & & \\
\hline
\end{tabular}

FE fold enrichment. 
Table 3 Chromosome 21 transcripts sorted by the coefficient of variation in both DS and control samples

\begin{tabular}{cccccc}
\hline \multicolumn{5}{c}{ DS samples } \\
& \multicolumn{1}{c}{$\mathbf{C V} \leq \mathbf{0 . 2}$} & $\mathbf{0 . 2}<\mathbf{C V}<\mathbf{0 . 5}$ & $\mathbf{C V} \geq \mathbf{0 . 5}$ & TOTAL \\
\hline \multirow{4}{*}{ Controls } & $\mathrm{CV} \leq 0.2$ & 55 & 22 & 0 & 77 \\
& $0.2<\mathrm{CV}<0.5$ & 49 & 19 & 6 & 74 \\
& $\mathrm{CV} \geq 0.5$ & 6 & 7 & 3 & 16 \\
& TOTAL & 110 & 48 & 9 & 167 \\
\hline
\end{tabular}

$C V$ coefficient of variation, DS Down syndrome.

Pathway analysis identified ubiquitin-mediated proteolysis as the pathway mostly influenced by trisomy $21(\mathrm{p}=2.9 \mathrm{E}-5$; FE 4.8). Among genes involved in the ubiquitin-dependent proteolysis, a number of E2-conjugating enzymes (UBE2A, UBE2B, UBE2H), E3-ligases (UBE3A, ITCH, SMURF2, F-box proteins, MIB1) and deubiquitinating enzymes (USP1, USP2, USP8, USP12, USP15, USP28, USP32, USP33, USP34, USP38, USP47) resulted down-regulated. Microarray data were validated by qRT-PCR on 11 differentially expressed genes with different functions and by comparing their average expression ratios (DS/controls) with those of the array (Additional file 3).

\section{Selection of possible therapeutic compounds}

Connectivity map and PASS-assisted exploration were used to identify compounds whose molecular signatures counteracted those of DS lymphoblasts and to predict their therapeutic potential, respectively. We found 17 compounds

Table 4 GO categories of the 55 chromosome 21 transcripts tightly regulated in DS and controls (CV $\leq \mathbf{0 . 2})$

\begin{tabular}{|c|c|c|c|c|}
\hline GO term & Genes & $\% *$ & p-value & FE \\
\hline \multirow[t]{4}{*}{ Cofactor metabolic process } & SOD1 & \multirow[t]{4}{*}{9.5} & \multirow[t]{4}{*}{0.0077} & \multirow[t]{4}{*}{9.4} \\
\hline & FTCD & & & \\
\hline & PDXK & & & \\
\hline & CRYZL1 & & & \\
\hline \multirow{3}{*}{$\begin{array}{l}\text { ATPase activity, coupled to } \\
\text { transmembrane movement } \\
\text { of substances }\end{array}$} & ATP5O & \multirow[t]{3}{*}{9.5} & \multirow[t]{3}{*}{0.0018} & \multirow[t]{3}{*}{15.9} \\
\hline & ATP5J & & & \\
\hline & ABCG1 & & & \\
\hline \multirow[t]{3}{*}{ Oxidative phosphorylation } & ATP5O & \multirow[t]{3}{*}{7.1} & \multirow[t]{3}{*}{0.016} & \multirow[t]{3}{*}{14.9} \\
\hline & ATP5J & & & \\
\hline & NDUFV3 & & & \\
\hline \multirow{2}{*}{$\begin{array}{l}\text { Mitochondrial proton-transporting } \\
\text { ATP synthase complex, coupling } \\
\text { factor } F(0)\end{array}$} & ATP5O & \multirow[t]{2}{*}{4.8} & \multirow[t]{2}{*}{0.016} & \multirow[t]{2}{*}{120.4} \\
\hline & ATP5J & & & \\
\hline \multirow{2}{*}{$\begin{array}{l}\text { Regulation of cholesterol } \\
\text { biosynthetic process }\end{array}$} & ABCG1 & \multirow[t]{2}{*}{4.8} & \multirow[t]{2}{*}{0.019} & \multirow[t]{2}{*}{100.3} \\
\hline & SOD1 & & & \\
\hline
\end{tabular}

FE fold enrichment, *\% of genes in category.
Table 5 Enriched pathways of the $\mathbf{5 5}$ chromosome 21 transcripts tightly regulated in DS and controls (CV $\leq \mathbf{0 . 2})$

\begin{tabular}{lllll}
\hline \multicolumn{1}{c}{ Pathway term } & Genes & $\%$ & p-value & FE \\
\hline Parkinson's disease & ATP5O & 9.5 & 0.002 & 13.8 \\
& ATP5J & & & \\
& NDUFV3 & & & \\
& UBC6/7 & & & \\
Huntington's disease & ATP5O & 9.5 & 0.0062 & 9.2 \\
& ATP5J & & & \\
& NDUFV3 & & & \\
Oxidative phosphorylation & SOD1 & & & \\
& ATP50 & 7.1 & 0.03 & 9.9 \\
& ATP5J & & & \\
Alzheimer's disease & NDUFV3 & & & \\
& ATP5O & 7.1 & 0.049 & 7.6 \\
& ATP5J & & & \\
\hline
\end{tabular}

$\mathrm{FE}$, fold enrichment.

with enrichment score $<-0.7$ (Additional file 4). Among these, adiphenine, eticlopride and vigabatrin display a predicted proteasome ATPase inhibitor activity (Pa score $0.72,0.65$ and 0.59 , respectively). Adiphenine also displays a putative ubiquitin thiolesterase inhibitor and a proteasome endopeptidase complex inhibitor activity (Pa score 0.58 and 0.56 , respectively). Finally, oxybenzone display a free radical scavenger activity ( $\mathrm{Pa} 0.79)$.

\section{Validation of some significantly deregulated GO categories \\ Protein ubiquitination and proteasome activity}

Ubiquitinated protein levels were measured by Western blot with or without proteasome block by MG132. Results in both LCLs and fetal fibroblasts showed a reduction of the ubiquitination state in DS resting cells and an increase following MG132 treatment (Figure 2A, B).

As chronic oxidative stress (OS) is a feature of DS and a defective response to OS is known to occur in DS with accumulation of protein damage [58], ubiquitinated protein levels were also measured after incubation with $0.1 \mathrm{mM}$ $\mathrm{H}_{2} \mathrm{O}_{2}$. DS cells showed a trend to increase ubiquitinbound proteins after OS induction. After $\mathrm{H}_{2} \mathrm{O}_{2}$ withdrawal, DS cells showed a more efficient recovery in the first two hours compared to controls (Figure 3). As the increase of ubiquitination following proteasome blocking suggested a possible involvement of the proteasome, the three proteasome activities were tested in LCLs before and after incubation with $\mathrm{H}_{2} \mathrm{O}_{2}$. Proteasome activity assay revealed a significant increase in the trypsin-like and in the chymotrypsin-like activities $(\mathrm{p}<0.01)$ in DS subjects, 
Table 6 Enriched GO categories of down-regulated genes $(p<0.01)$, sorted by $p$-value

\begin{tabular}{|c|c|c|c|c|c|}
\hline Biological process & GO term & N. of genes & $\% *$ & p-value & $\mathrm{FE}$ \\
\hline \multirow[t]{7}{*}{ Ubiquitin metabolism } & ubiquitin-dependent protein catabolic process & 16 & 5.4 & $5.2 \mathrm{E}-6$ & 4.3 \\
\hline & modification-dependent protein catabolic process & 25 & 8.5 & $1.4 \mathrm{E}-5$ & 2.7 \\
\hline & proteolysis involved in cellular protein catabolic process & 25 & 8.5 & $2.9 \mathrm{E}-5$ & 2.6 \\
\hline & ligase activity & 17 & 5.8 & 0.001 & 2.6 \\
\hline & proteolysis & 29 & 9.8 & 0.009 & 1.6 \\
\hline & ubiquitin-protein ligase activity & 8 & 2.7 & 0.013 & 3.2 \\
\hline & proteasomal ubiquitin-dependent protein catabolic process & 6 & 2.0 & 0.025 & 3.6 \\
\hline \multirow[t]{3}{*}{ Cell signalling } & positive regulation of I-kB kinase/NF-kB cascade & 9 & 3.1 & 0.0002 & 5.5 \\
\hline & positive regulation of protein kinase cascade & 10 & 3.4 & 0.0024 & 3.5 \\
\hline & positive regulation of signal transduction & 12 & 4.1 & 0.01 & 2.4 \\
\hline Protein localization & establishment of protein localization & 25 & 8.5 & 0.002 & 2.0 \\
\hline \multirow[t]{6}{*}{ Cell cycle } & mitotic cell cycle & 14 & 4.7 & 0.008 & 2.3 \\
\hline & cell cycle phase & 15 & 5.1 & 0.009 & 2.2 \\
\hline & M phase of mitotic cell cycle & 10 & 3.4 & 0.013 & 2.7 \\
\hline & mitosis & 9 & 3.1 & 0.031 & 2.4 \\
\hline & nuclear division & 9 & 3.1 & 0.031 & 2.4 \\
\hline & interphase & 6 & 2.0 & 0.033 & 3.3 \\
\hline \multirow[t]{3}{*}{ Regulation of gene expression } & gene expression & 62 & 21.0 & 0.022 & 1.3 \\
\hline & mRNA processing & 12 & 4.1 & 0.023 & 2.2 \\
\hline & RNA splicing & 11 & 3.7 & 0.024 & 2.3 \\
\hline Vescicle related & ER to Golgi vesicle-mediated transport & 4 & 1.4 & 0.033 & 5.6 \\
\hline
\end{tabular}

FE fold enrichment, $* \%$ of genes in category.

both in basal and OS conditions, while no differences were observed for the caspase-like activity (Figure 4).

\section{IkB-alfa/NF-kB}

NF- $k B$ is finely regulated by a complex network of gene products and post-translational modifications. To demonstrate if a NF- $k$ B defect occurs in DS, we choose to analyse the down-stream product of the NF- $k B$ cascade, i.e. the behaviour of p50/p65 and of its inhibitors in DS cell lines. Levels of p50, p65, IkB-alfa and phospho-IkB-alfa proteins were assessed by Western blot using specific antibodies in DS and control samples. Results showed a significant reduction of p65 levels in the nuclear fractions and a significant increase of $\mathrm{I} k \mathrm{~B}$-alfa in the cytosolic fractions of DS subjects, in both the dephosphorylated and phosphorylated forms (Figure 5A, B, C). No difference was observed for NF- $k$ B p50 subunit levels (data not shown). Luciferase assay confirmed a significant reduction of NF- $k$ B transcriptional activity in DS LCLs $(\mathrm{p}<0.05)$ (Figure 5D). Immunoprecipitation of $\mathrm{I} k \mathrm{~B}$-alfa in cytosolic fractions and subsequent Western blot with specific anti-ubiquitin antibody showed a reduction of the ubiquitinated levels of this inhibitor under basal conditions in DS fractions (Figure 6A). Ubiquitination levels returned similar to controls after proteasome blocking (Figure 6B).
Table 7 Enriched GO categories of the up-regulated genes $(p<0.01)$, sorted by $p$-value

\begin{tabular}{|c|c|c|c|c|c|}
\hline $\begin{array}{l}\text { Biological } \\
\text { process }\end{array}$ & GO term & $\begin{array}{l}\text { N. of } \\
\text { genes }\end{array}$ & $\% *$ & $\begin{array}{c}\mathrm{p}- \\
\text { value }\end{array}$ & FE \\
\hline \multirow{8}{*}{$\begin{array}{l}\text { Transport and } \\
\text { localization }\end{array}$} & calcium ion transport & 5 & 8.3 & 0.001 & 10.6 \\
\hline & $\begin{array}{l}\text { transmembrane } \\
\text { transport }\end{array}$ & 7 & 11.7 & 0.01 & 3.7 \\
\hline & metal ion transport & 6 & 10.0 & 0.016 & 3.9 \\
\hline & localization & 17 & 28.3 & 0.022 & 1.7 \\
\hline & cation transport & 6 & 10.0 & 0.032 & 3.3 \\
\hline & transport & 15 & 25.0 & 0.034 & 1.7 \\
\hline & ion transport & 7 & 11.7 & 0.035 & 2.8 \\
\hline & $\begin{array}{l}\text { establishment of } \\
\text { localization }\end{array}$ & 15 & 25.0 & 0.037 & 1.7 \\
\hline \multirow[t]{6}{*}{ Development } & $\begin{array}{l}\text { cellular developmental } \\
\text { process }\end{array}$ & 14 & 23.3 & 0.002 & 2.5 \\
\hline & $\begin{array}{l}\text { anatomical structure } \\
\text { development }\end{array}$ & 17 & 28.3 & 0.004 & 2.0 \\
\hline & cell differentiation & 13 & 21.7 & 0.005 & 2.4 \\
\hline & system development & 16 & 26.7 & 0.005 & 2.1 \\
\hline & $\begin{array}{l}\text { multicellular organismal } \\
\text { development }\end{array}$ & 17 & 28.3 & 0.015 & 1.8 \\
\hline & organ development & 12 & 20.0 & 0.021 & 2.1 \\
\hline
\end{tabular}

FE fold enrichment, $* \%$ of genes in category. 

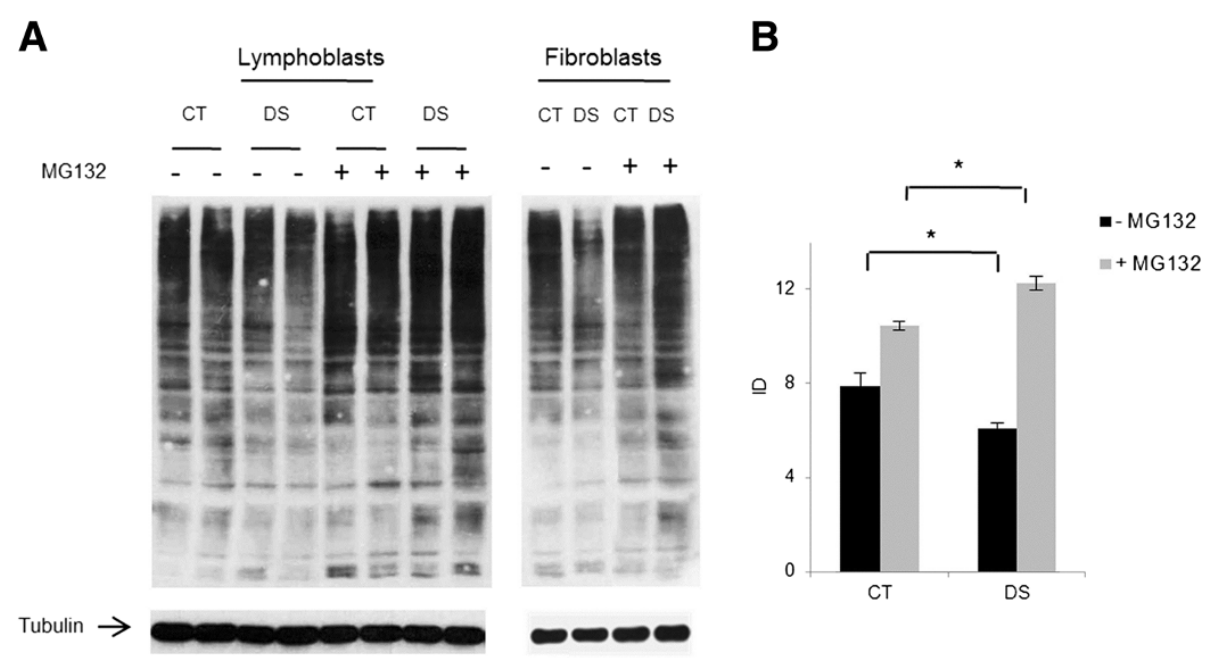

Figure 2 Western blot analysis of total ubiquitin-bound protein levels. A) Western blot performed on lymphoblasts and fetal fibroblasts in basal conditions and following proteasome blocking (40 $\mu \mathrm{M}$ MG132 for six hours). B) Histograms show the average protein ubiquitination of lymphoblasts derived from two controls and two DS subjects, normalized on tubulin levels. ${ }^{*} p<0.05$.

\section{DYRK1A/DSCR1/NFAT genes}

DYRK1A, DSCR1 and the members of the NFAT transcription factors were evaluated by RT-PCR and Western blot. We observed a significant upregulation of DYRK1A, DSCR1 and NFATc4 (about 2-fold increase) and a down-regulation of NFATc2 (69\% reduction) and NFATc1 (49\% reduction) expression profiles in DS LCLs compared to controls (Figure 7A). No difference was observed for NFATc3. At protein level, we confirmed the significant reduction of NFATc2 and the increase of DYRK1A and DSCR1 (Figure 7B) while no difference was observed for NFATc1 and NFATc4 (data not shown). To assess NFAT nuclear translocation, Western blot experiments were performed upon induction of calcium fluxes through PMA/ionomycin. Results showed a reduction of NFATc2 nuclear levels following stimulation, suggesting the presence of mechanisms acting to inhibit its translocation (Figure 8).

Finally, soluble DSCR1 protein levels were investigated before and after proteasome blocking. Results showed a reduction of soluble DSCR1 levels in both samples after MG132 treatment, with a more marked effect in DS

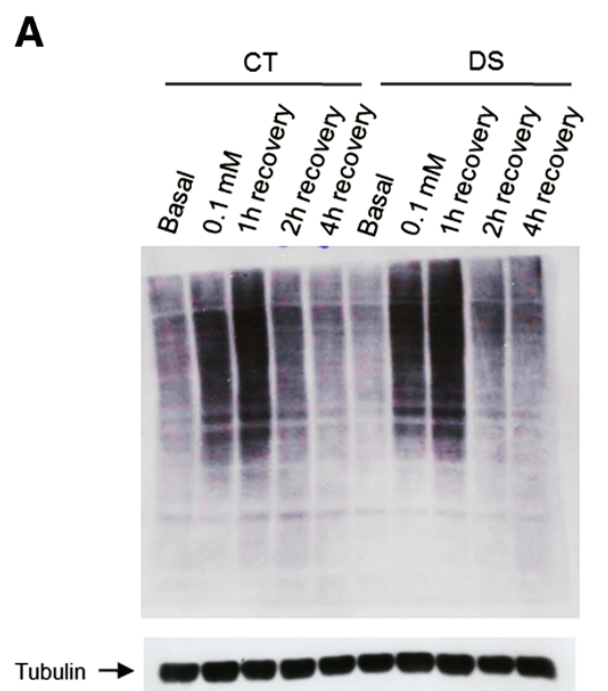

B

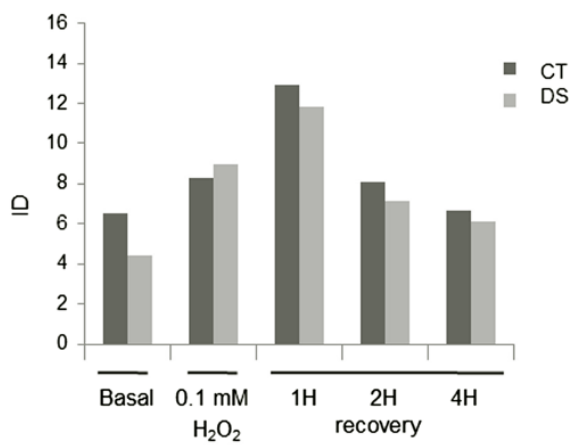

Figure 3 Ubiquitin-bound proteins in LCLs from a DS and a control subject in basal and OS conditions. A) Western blot analysis of ubiquitin-bound proteins in lymphoblasts from a DS and a control subject in basal conditions, under oxidative stress $\left(0,1 \mathrm{mM} \mathrm{H}_{2} \mathrm{O}_{2}\right.$ for 30 minutes) and after 1,2 and 4 hours of recovery. B) relative densitometry. 


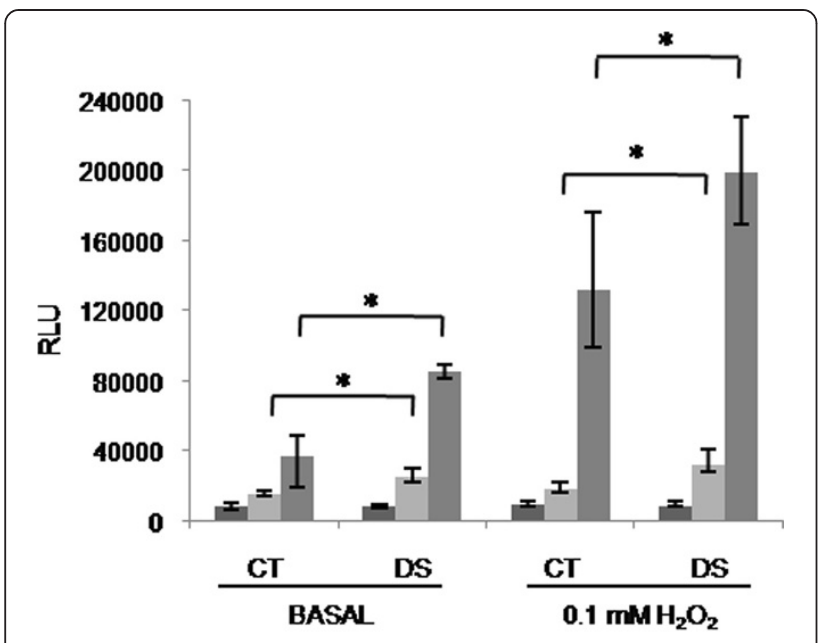

- CASPASE-UKEACTINII

" TRYPSNHKE ACINITY

- CHYMOIRYPSNHKE ACIMIY

Figure 4 Proteasome activity assay from LCLs, in basal conditions and after treatment with $0,1 \mathrm{mM} \mathrm{H}_{2} \mathrm{O}_{2}$ for

$\mathbf{3 0}$ minutes. Histograms show the average of the activities of DS

subjects $(n=3)$ versus controls $(n=3)$, evaluated in duplicate and repeated twice. ${ }^{*} p<0.05$.

subjects where the DSCR1 levels became comparable to controls (Figure 9).

\section{Discussion}

In spite of the great efforts made to analyze the effects of dosage imbalance at molecular level, the pathogenesis of DS is still unclear. So far, expression studies performed with distinct approaches led to inconclusive results, thus underlining the importance of integrating microarray data with functional validation of selected pathways.

The present study was aimed at analyzing gene expression profiles in LCLs from DS and controls to identify genes and metabolic pathways involved in DS pathogenesis, with an emphasis toward chr 21 genes. To select reliable GO classes, two distinct web-based softwares working on different statistic algorithms (DavidBioinformatics and GOTM) were used. These GO classes where further analysed to provide experimental evidence of their disruption in DS.

Despite some inherent limitations, the utility of LCLs is increasingly recognized in both genetic and functional studies [59]. Considering the similarity of the expression and regulation of certain genes between LCLs and neurons, LCLs have been used as surrogate cells in studies of neurological disorders as in the case of Parkinson's disease [60,61] and Alzheimer's disease [62]. LCLs have also been successfully used to study mitochondrial and organellar dysfunction as in the case of autophagy in juvenile neuronal ceroid lipofuscinosis [63]. Beside the present study, LCLs have been used in expression studies of chr 21 genes in three previous works [21,23,38] where it was demonstrated that the variance on gene expression levels due to culture conditions is extremely low in this cell model [21]. Moreover, Merla et al., [64] established six independent LCLs for the same individual and compared expression levels for $25 \mathrm{chr} 21$ genes finding a strong correlation ranging from 0.8 to 0.92 . In this study, to maximize the quality of LCLs, each aliquot of LCLs was maintained in culture for no longer than 3 months (less than 160 'population doubling levels') and cells were karyotyped before microarray analysis and before each experimental validation to exclude the possibility of chromosomal rearrangements (other than full trisomy 21).

\section{Overexpression of chr 21 genes}

Our results showed a significant up-regulation of a subset of 59 chr 21 genes $(\mathrm{p}<0.05)$ with a mean DS/control ratio of $1.36 \pm 0.2$. This confirms that most trisomic genes escape the predicted gene-dosage rule of 1.5 -fold increase and underscores the existence of complex and unravelled mechanisms of transcriptional regulation [65]. In the present study, GO analysis of the overexpressed chr 21 genes indicated ATPase activity coupled to transmembrane movement of substances and oxidative phosphorylation as the major enriched categories. This result is in agreement with previous gene expression studies in fetal DS cerebral cortex, heart and trophoblasts $[5,7,13,15]$ in which the most consistently disregulated chr 21 genes were those involved in mitochondrial function related metabolic pathways, such as ATP5O and ATP5J (encoding two mitochondrial ATP synthase subunits), NDUFV3 (subunit of NADH dehydrogenase), and SOD1 (involved in antioxidant defense system). Mitochondrial dysfunction has been proposed in the pathogenesis of DS for years. In particular, deficit of oxidative phosphorylation due to a deregulation of the mitochondrial respiratory chain complexes I, III and V [34,35,66-68], increased levels of the Krebs cycle enzymes (aconitase and NADP-linked isocitrate dehydrogenase) [69] and impaired mtDNA repair systems [70] were described in human DS cells. In isolated mitochondria from DS mice cortex, a decreased membrane potential and ATP content and selective defects in Complex-I mediated respiration were also found [71]. Furthermore, a close relationship between mitochondrial abnormalities and oxidative damage has been described in DS brains and fibroblasts [72]. Mitochondrial dysfunctions can result either in decreased ATP levels, or in increased ROS production [35,73]. Mitochondrial dysfunction was also described in neurodegenerative diseases such as Alzheimer's, Parkinson's and Huntington's diseases 


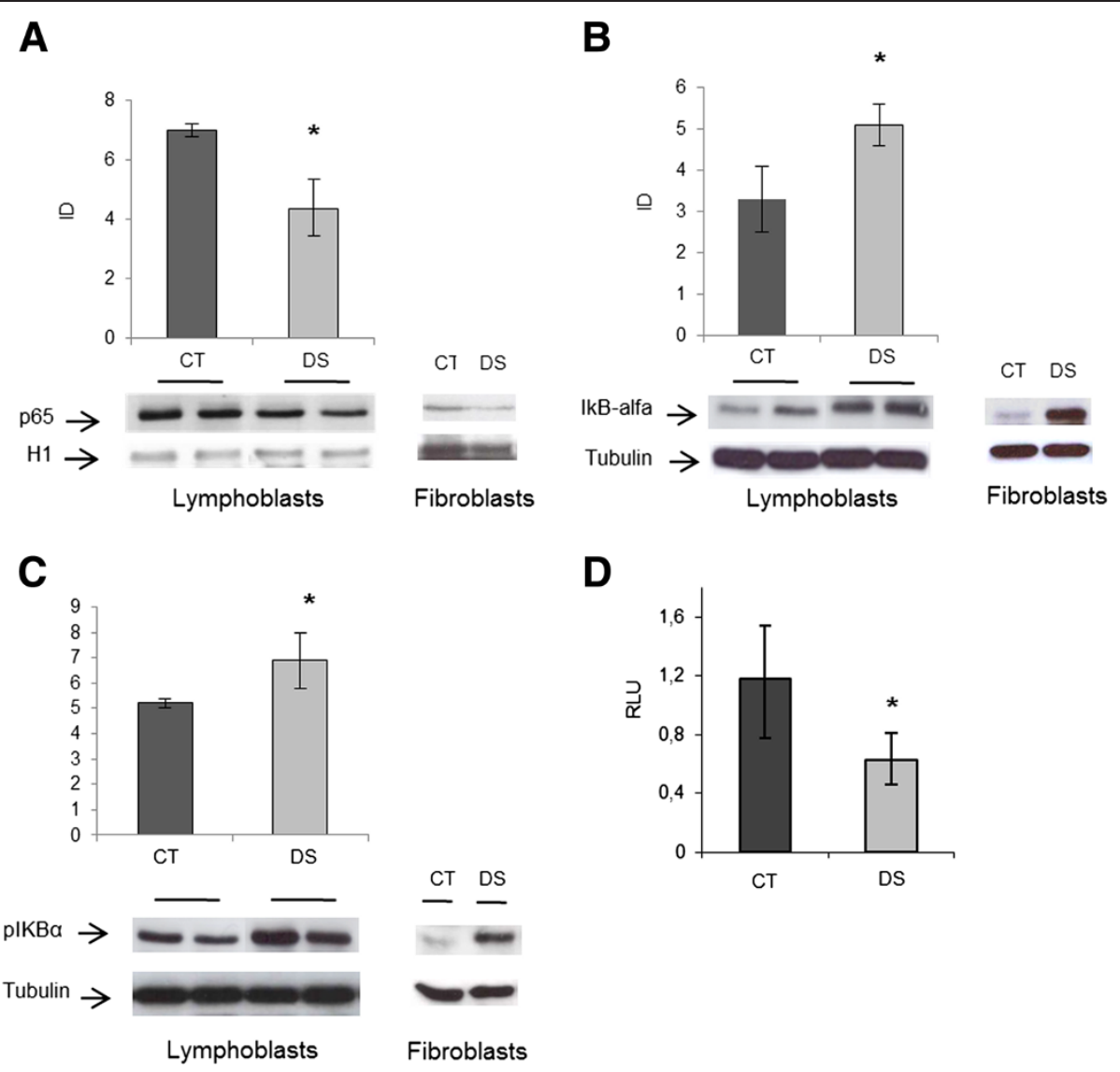

Figure 5 NF-kB p65, IkB-alfa and phospho-lkB-alfa in LCLs and fibroblats and relative densitometry. A) Western blot of NF-kB p65 nuclear levels and B-C) IkB-alfa and phospho-lkB-alfa cytosolic levels LCLs and relative densitometry. p65, IkB-alfa and phospho-lkB-alfa protein levels in fetal fibroblasts from one DS subject and one control are shown as well. As internal controls, tubulin and $\mathrm{H} 1$ histone were used for cytosolic and nuclear marker proteins, respectively. D) NF-kB Luciferase assay in lymphoblasts. Histograms show the average of the activity, expressed as relative light units (RLU), of DS subjects ( $n=3)$ versus controls $(n=3)$ normalized on the average of the b-galactosidase activity. Experiments were performed in triplicate and repeated twice. ${ }^{*} p<0.05$.

and in the normal aging processes [73-77]. Interestingly, when the trisomic genes, upregulated in the present gene expression study, were submitted to pathway analysis, Alzheimer's, Parkinson's and Huntington's diseases were identified as the most deregulated, in agreement with the meta-analysis from heterogeneous human and mouse DS data sets [27]. Finally, when only the amplified chr 21 genes tightly regulated in DS and in control subjects were submitted to in silico analysis, the same categories and pathways were identified. Taken together, these findings suggest that genes directly or indirectly involved in the oxidative phosphorylation, ATPase activity and, in general, in mitochondrial function, may have a role in the pathogenesis of DS phenotypes.

\section{Genome-wide deregulation and pathway perturbation induced by trisomy 21}

The genome-wide expression analysis revealed that $30.7 \%$ and $17.5 \%$ of genes were up-regulated at $\mathrm{p}<0.05$ and $\mathrm{p}<0.01$, respectively. A low percentage of upregulated genes was also reported in two previous studies on LCLs, showing that $29 \%$ and $39 \%$ of genes were up-regulated, respectively [21,23]. In this study, genes involved in ubiquitin metabolism, cell signalling (with a particular enrichment of NF- $k$ B cascade), cell cycle, protein localization and regulation of gene expression were down-regulated, and genes involved in developmental processes and calcium ion transport were up-regulated. The latter results are in agreement with previous genome-wide studies that reported the impairment of GO categories associated to developmental processes, both in fetal and adult DS biomaterials [9,14], as well as of calcium/potassium signalling on cell-free mRNA from amniotic fluid [78].

At mRNA level, while the ubiquitin pathway was reported as deregulated in DS trophoblasts and in rRNA-depleted samples from DS endothelial progenitor cells (EPCs) [15,79], NF- $k$ B cascade, linked to the 

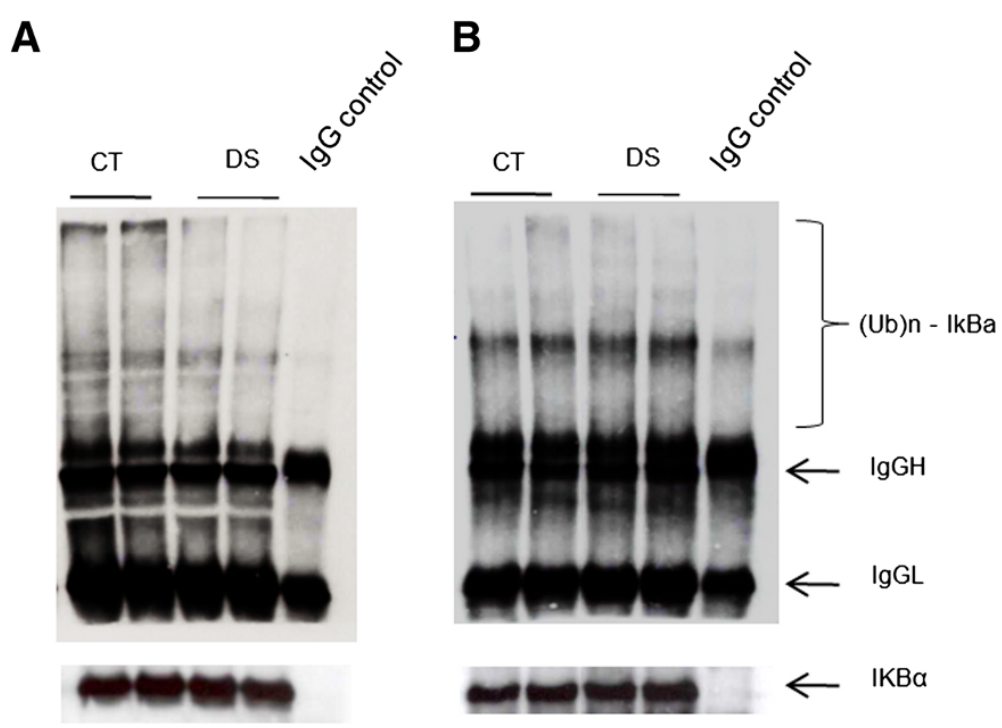

Figure 6 Ubiquitination of IkB-alfa in basal conditions (A) and after proteasome blocking with $40 \mu \mathrm{M}$ MG132 for six hours (B). Cytoplasmic extracts were immunoprecipitated for IkB-alfa and then analyzed by western blot using an antibody against ubiquitin. IgG $\mathrm{H}$ and IgG $L$ indicate immunoglobulin heavy and light chains in the immunoprecipitates that cross-react with the secondary antibody.

ubiquitn-mediated proteolysis, was found down-regulated in the present study for the first time. The close relation between the ubiquitin-mediated proteolysis and NF- $k B$ and their relevance to a wealth of human disorders make these two pathways attractive candidates for DS pathogenesis.

\section{The ubiquitin-dependent proteolysis}

The UPS is the major proteolytic pathway used by eukaryotic cells to metabolize proteins [80]. Proteins to be degraded are covalently linked to a polyubiquitin chain by three different enzymes and then targeted to the $26 \mathrm{~S}$ proteasome where are disassembled in small peptides, amino acids and ubiquitin monomers. UPS is known to metabolize misfolded, oxidized and damaged proteins, but also proteins involved in signal transduction, cell cycle regulation, differentiation and development, cellular response to stress, regulation of the immune and inflammatory response. A link between protein synthesis and degradation by UPS has been proposed [81]. Hence, derangements in this system, that can be associated to loss of function (mutation in an ubiquitin system enzyme or target substrate) or gain of function (abnormal or accelerated degradation of the target protein) could underlie, directly or indirectly, the pathogenesis of many diseases, including some features belonging to the DS spectrum. In particular, accumulation of ubiquitin conjugates and/or inclusion bodies

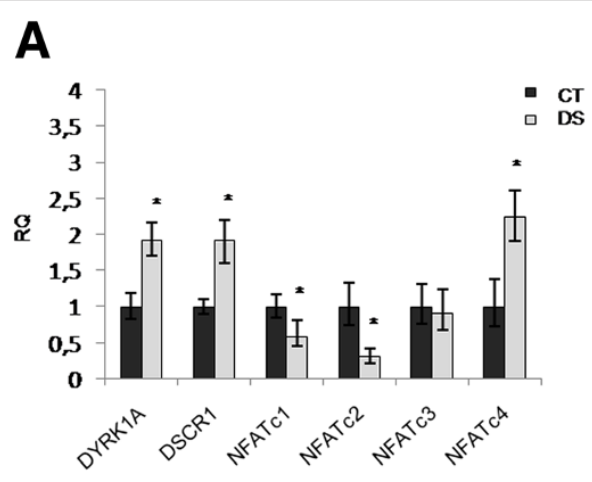

B

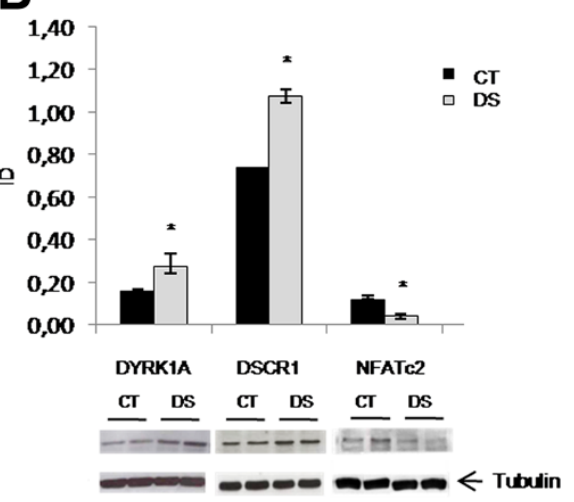

Figure 7 Analysis of DYRK1A, DSCR1 and NFATc1-4 gene products in LCLs. A) Relative quantification. Histograms show mRNA levels of pools of DS subjects $(n=3)$ versus controls $(n=3)$. All data are expressed relatively to control subjects, to which is assigned a value of 1 -fold $(1 x)$. B) Western blot of total protein levels. * $p<0.05$. 


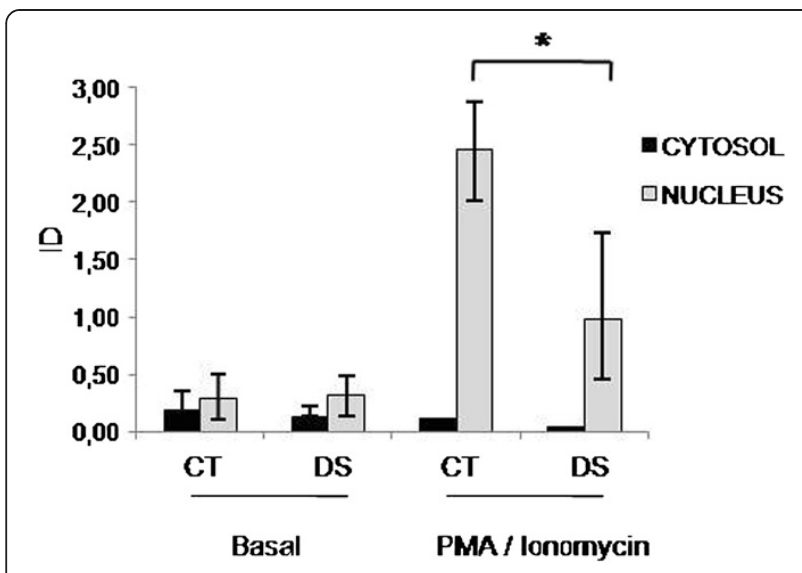

Figure 8 Analysis of activation and nuclear translocation of NFATc2, induced by PMA/lonomycin. As internal controls, tubulin and $\mathrm{H} 1$ histone were used for cytosolic and nuclear marker proteins, respectively. ${ }^{*} p<0.05$.

associated with ubiquitins have been reported in a broad array of chronic neurodegenerative diseases, such as the neurofibrillary tangles of Alzheimer's disease (AD), brain stem Lewy bodies (LBs) in Parkinson's disease (PD) and intracellular bodies in Huntington's disease [82]. In these cases, an involvement of the UPS was suggested [83-85]. So far, no data were available on the ubiquitination status and proteasome activity in human DS. By means of a protein screen by SDS-page, a study showed an increase of the proteasome zeta chain, an alpha subunit of the $20 \mathrm{~S}$ proteasome, and of isopeptidase $\mathrm{T}$, a deubiquitinating enzyme, in fetal DS brain [86]. More recently, a study on the cerebellum of Ts65Dn mice showed a reduction of the proteasome chymotrypsin-like activity and an increase of ubiquitinated proteins [87], results possibly ascribable to

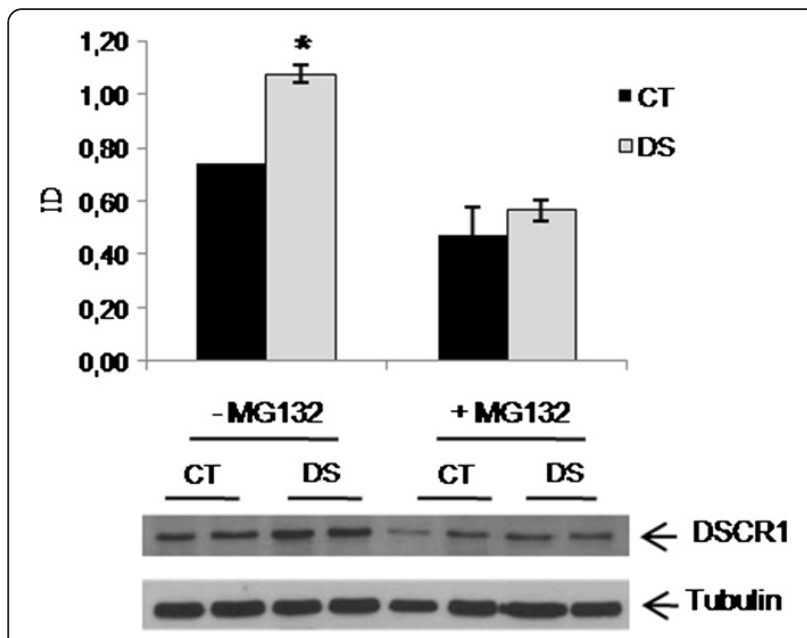

Figure 9 Western blot analysis of DSCR1 protein levels in basal conditions and following proteasome blocking with $40 \mu \mathrm{M}$ MG132 for six hours in lymphoblasts from 2 DS and 2 control subjects. ${ }^{*} p<0.05$. the increased levels of beta-amyloid found in Ts65Dn mice brains [88].

The present study in human cell lines shows for the first time that, under basal conditions, there is a reduction of ubiquitinated protein levels in DS. This observation may either depend on defective ubiquitin-protein ligase activity (as suggested by microarray data) or on increased proteasome function, as demonstrated by the increase of two out of the three proteasome activities. Under OS, we observed an increase of ubiquitinated proteins in DS compared to the control sample. In the recovery period, ubiquitinated proteins were efficiently cleared in DS, probably due to the observed increase of the proteasome activities during OS. Previous studies have shown that chronic OS is a feature of DS [35,36,71,89-92]. Increased protein damage has also been shown in DS [58]. These observations may explain the increased proteasome activity, the accumulation of Ubbound proteins after proteasome blocking with MG132 and, at least in part, the reduction of ubiquitin-bound proteins. These findings offer a new perspective to study this system in association to relevant DS pathological features, such as neurodegeneration, autoimmune disorders and predisposition to cancer.

\section{IkB-alfa/NF-kB}

The UPS is implicated in numerous cellular processes including activation of transcription factors such as NF$k \mathrm{~B}$. The NF- $k \mathrm{~B}$ family of transcription factors is critical in the development and maintenance of the immune system. Five NF- $k B$ subunits exist and the most abundant and active form is a heterodimer composed of p50 and p65. Generally, this heterodimer is sequestered in the cytosol by one of the I $k \mathrm{~B}$ inhibitors, most commonly $\mathrm{I} k \mathrm{~B}$-alfa and is activated only upon I $k \mathrm{~B}$ phosphorylation and subsequent proteasome mediated degradation [47]. Since this transcription factor is connected to a wide array of immune and inflammatory disorders, along with cell apoptosis and delay of cell growth, disruption of its pathway could play an important role in DS pathogenesis. In the present study, the GO analysis showed a down-regulation of the NF- $k B$ cascade. Our experimental data provide the first evidence of a reduction of the NF- $k$ B p65 subunit in DS nuclear fractions and of a significant reduction of its transcriptional activity. Along with this observation, cytosolic I $k \mathrm{~B}$-alfa levels were increased, in both the phosphorylated and dephosphorylated form. Ubiquitin-bound IkB-alfa was however reduced. These results, in agreement with the data of the total protein ubiquitination state, may be due to proteasome hyperfunction or to a defect of specific ubiquitin ligases activities, such as F-box proteins, or the recently described MIB1 [93], downregulated in this microarray experiment. As NF- $k B$ signalling is 
deeply modulated by ubiquitination at several levels $[94,95]$, further studies on the regulation of NF- $k$ B by ubiquitination in DS may add new clues to the pathogenesis of DS.

An additional level of interest comes from recent evidence of an interplay between NF- $k B$ and NFAT pathway. In fact, NF- $k \mathrm{~B}$-inducing kinase interacts with and specifically phosphorylates the C-terminal region of DSCR 1 in immortalized hippocampal cells as well as in primary cortical neurons, increasing DSCR1 protein stability and blocking its proteasomal degradation [44]. This could lead to an increase in soluble and insoluble DSCR1 levels that are cytotoxic [29]. Moreover, DSCR1 overexpression stabilizes I $k \mathrm{~B}$-alfa and decreases the steady-state activity of NF$k \mathrm{~B}$, thus inhibiting the induction of genes involved in the inflammatory response [30].

\section{The role of DYRK1A/DSCR1/NFAT genes in DS}

The nuclear factors of activated T cells (NF-ATs) are a family of transcription factors that transduce calcium signals in the immune, cardiac, muscular, and nervous systems [96]. Like their distant relatives, the Rel family, which includes NF- $k$ B, NFATs are located in the cytoplasm of resting cells and are activated for nuclear translocation [97]. Calcium signalling activates calcineurin and induces the movement of NFAT proteins into the nucleus, where they cooperate with other proteins to form complexes on DNA. As DYRK1A and DSCR1 regulate NFAT nuclear translocation, in the present study the DYRK1A/DSCR1/NFAT genes were analysed. DYRK1A at both RNA and protein levels resulted significantly overexpressed in DS. The same result was obtained for DSCR1, while a reduction of NFATc2 was observed at mRNA and protein level in DS resting cells. Reduction of NFATc2 was also observed in the nuclear fractions of DS after calcium flows stimulation. Together with the reduced NF- $k$ B activity, this observation suggests the presence of a transcriptional regulation deficit in DS.

\section{Conclusions}

Results from the present microarray analysis in human LCLs show that the UPS functioning is impaired in DS. Among genes contributing to the ubiquitin mediated proteolysis and represented on the array, a number of E2conjugating enzymes (such as UBE2A, UBE2B, UBE2H) and E3 ligases (such as UBE3A, ITCH, SMURF2, MIB1 and some F-box proteins) resulted down-regulated. Additional bioinformatic tools such as Connectivity Map and PASS analysis add supportive evidence of the involvement of the UPS in the pathogenesis of DS. Experimental data confirm a reduction of Ub-bound proteins and an increased proteasomal acitivity. Proteasome activity may be accelerated by increased damaged or misfolded proteins and/or by chronic oxidative stress, a known biochemical feature of DS resulting from either gene dosage effect of certain chr 21 genes (i.e. SOD1, CBS, APP) or mitochondrial dysfunction $[36,89,98,99]$.

Increased proteasome activity, along with defective ubiquitination, may lead to reduction of Ub-bound proteins, including critical regulators of cellular homeostasis such as transcriptional activators or their inhibitors. Expression analysis pointed to a down-regulation of NF- $k$ B, the final actor of a complex pathway of signal transduction finely modulated by ubiquitination at several levels [94]. Interestingly, definition of crosstalk between NF- $k$ B signalling pathway, ubiquitin-dependent proteolysis and the critical chr 21 gene DSCR1 is still ongoing.

Because of its central role in the cell life, the proteasome has become a target for synthetic and natural drugs for the prevention and treatment of several conditions [100-102]. An example of the medical importance of its inhibition could be the stabilization of the transcription factor NF- $k$ B, required to preserve cell viability in response to environmental stress or cytotoxic agents [103-105]. Furthermore, as suggested by our findings, also the DSCR1 protein levels, overexpressed in trisomic subjects, may be regulated by the proteasome inhibition.

Recent biochemical and epidemiological studies indicate that dietary minor components, such as polyphenols, may have a role in the defense against the OS in vivo [106]. Among the different phenolic compounds, epigallocatechin3-gallate (EGCG), the major catechin of green tea, mitigates OS and inhibits the chymotrypsin-like activity of the proteasome [107-110]. Interestingly, the over-expression of DYRK1A can also be modulated by EGCG [111] and transgenic mice overexpressing this gene and presenting cognitive impairment, rescue the cognitive phenotype after a polyphenol-based diet [112]. Our functional analyses revealed an increase of the proteasome chymotrypsinlike activity in DS subjects and the Connectivity map and PASS-assisted exploration of our microarray data suggested that some compounds with proteasome inhibitor activity could revert the biological status of DS.

In conclusion, the present work offers new perspectives to better understand the pathogenesis of DS disease and suggests a rational for innovative approaches to DS treatment.

\section{Availability of supporting data}

Microarray data were deposited in the ArrayExpress database (http://www.ebi.ac.uk/arrayexpress/) (accession n. E-MTAB-1238).

\section{Additional files}

Additional file 1: A) Volcano plot of genes differentially expressed in trisomic vs control samples. B) Clustering of genes and conditions at $\mathrm{p}$-value $<0.05 ; \mathbf{C}$ ) Clustering of genes and conditions at $\mathrm{p}$-value $<0.01$ 
(GeneTree Algorithm). The log2 of fold change between trisomic and control samples is represented on the $\mathrm{x}$-axis and the negative log of $\mathrm{p}$ values from the $t$-test is represented on the $y$-axis. Up-regulated genes are represented on the right side of the horizontal axis 0-value; downregulated gene are on the left. Red dots indicate genes that are significantly up- or down-regulated at $p<0.01$. Fold-change filter in DS vs controls $\geq 1.2$. Supervised hierarchical clustering of both the 4,490 and the 406 transcripts clearly distinguish between DS and control samples.

Additional file 2: List of chr 21 transcripts, tightly regulated in both DS and control samples ( $C V \leq 0.2)$.

Additional file 3: Average expression ratios and Pearson's correlation coefficient $(r)$ between microarray and RT-PCR data.

Additional file 4: Selection of compounds with possible therapeutic potential in DS according to the Connectivity Map and the PASSonline software.

\section{Abbreviations}

DS: Down syndrome; chr: chromosome; LCLs: Lymphoblastoid cell lines; NFAT: Nuclear factor of activated T-cells; UPS: Ubiquitin-proteasome system; NF-kB: Nuclear factor-kB; FC: Fold change; FE: Fold enrichment; CV: Coefficient of variation; OS: Oxidative stress; EGCG: Epigallocatechin-3gallate.

\section{Competing interests}

The authors declare that they have no competing interests.

\section{Authors' contributions}

BG carried out most of the experiments of cell cultures, western blot, functional studies and statistical analysis; IS conceived and designed the study, participated to data interpretation and drafted the manuscript; CS performed NFATc2 western blot; AV and MC participated to sample collection and carried out some of the western blot experiments; RAV participated to data interpretation and critically revised the manuscript; PDL performed microarray experiments and statistical analysis; GA was involved in the study coordination and in the critical revision of the manuscript, giving the final approval of the version to be published. All authors read and approved the final manuscript.

\section{Acknowledgements}

This work was supported by grants from the Italian Minister of Education, University and Research (MIUR) - PRIN to G.A. (2006067072, 2008FHM37R) and from Fondation Jerome Lejeune to R.V. (Vacca/1093-VR2012B). We thank the Galliera Genetic Bank - Network of Telethon Genetic Biobanks project GTB07001 for providing fibroblast cell lines.

\section{Author details}

'Department of Pediatrics, Federico II University, Naples 80131, Italy. ${ }^{2}$ Department of Biotechnological Sciences, Federico II University, Naples 80131, Italy. ${ }^{3}$ Institute of Biomembranes and Bioenergetics, National Council of Research, Bari 70126, Italy. ${ }^{4}$ Stazione Zoologica "A. Dohrn", c/o BioGeM, Via Camporeale, Ariano Irpino 83031, Italy.

Received: 18 February 2013 Accepted: 29 June 2013

Published: 5 July 2013

\section{References}

1. Amano K, Sago H, Uchikawa C, Suzuki T, Kotliarova SE, Nukina N, Epstein CJ, Yamakawa K: Dosage-dependent over-expression of genes in the trisomic region of Ts1Cje mouse model for Down syndrome. Hum Mol Genet 2004, 13:1333-40.

2. Lyle R, Gehrig C, Neergaard-Henrichsen C, Deutsch S, Antonarakis SE: Gene expression from the aneuploid chromosome in a trisomy mouse model of Down syndrome. Genome Res 2004, 14:1268-1274.

3. Kahlem P, Sultan M, Herwig R, Steinfath M, Balzereit D, Eppens B, Saran NG, Pletcher MT, South ST, Stetten G, Lehrach H, Reeves RH, Yaspo ML: Transcript level alterations reflect gene dosage effects across multiple tissues in a mouse model of Down syndrome. Genome Res 2004, 14:1258-1267.

4. Dauphinot L, Lyle R, Rivals I, Dang MT, Moldrich RX, Golfier G, Ettwiller L, Toyama K, Rossier J, Personnaz L, Antonarakis SE, Epstein CJ, Sinet PM,
Potier MC: The cerebellar transcriptome during postnatal development of the Ts1Cje mouse, a segmental trisomy model for Down syndrome. Hum Mol Genet 2005, 14:373-384.

5. Mao R, Zielke CL, Zielke HR, Pevsner J: Global up-regulation of chromosome 21 gene expression in the developing Down syndrome brain. Genomics 2003, 81:457-467.

6. Giannone S, Strippoli P, Vitale L, Casadei R, Canaider S, Lenzi L, D'Addabbo P, Frabetti F, Facchin F, Farina A, Carinci P, Zannotti M: Gene expression profile analysis in human $\mathrm{T}$ lymphocytes from patients with Down syndrome. Ann Hum Genet 2004, 68:546-554.

7. Mao R, Wang X, Spitznagel EL Jr, Frelin LP, Ting JC, Ding H, Kim JW, Ruczinski I, Downey TJ, Pevsner J: Primary and secondary transcriptional effects in the developing human Down syndrome brain and heart. Genome Biol 2005, 6:R107.

8. Li CM, Guo M, Salas M, Schupf N, Silverman W, Zigman WB, Husain S, Warburton D, Thaker H, Tycko B: Cell type-specific over-expression of chromosome 21 genes in fibroblasts and fetal hearts with trisomy 21. BMC Med Genet 2006, 7:24.

9. Altug-Teber O, Bonin M, Walter M, Mau-Holzmann UA, Dufke A, Stappert H, Tekesin I, Heilbronner H, Nieselt K, Riess O: Specific transcriptional changes in human fetuses with autosomal trisomies. Cytogenet Genome Res 2007, 119:171-84

10. FitzPatrick DR, Ramsay J, McGill NI, Shade M, Carothers AD, Hastie ND: Transcriptome analysis of human autosomal trisomy. Hum Mol Genet 2002, 11:3249-56.

11. Gross SJ, Ferreira JC, Morrow B, Dar P, Funke B, Khabele D, Merkatz I: Gene expression profile of trisomy 21 placentas: a potential approach for designing noninvasive techniques of prenatal diagnosis. Am J Obstet Gynecol 2002, 187:457-462.

12. Tang Y, Schapiro MB, Franz DN, Patterson BJ, Hickey FJ, Schorry EK, Hopkin RJ, Wylie M, Narayan T, Glauser TA, Gilbert DL, Hershey AD, Sharp FR: Blood expression profiles for tuberous sclerosis complex 2, neurofibromatosis type 1, and Down's syndrome. Ann Neurol 2004, 56:808-814.

13. Conti A, Fabbrini F, D'Agostino P, Negri R, Greco D, Genesio R, D'Armiento M, Olla C, Paladini D, Zannini M, Nitsch L: Altered expression of mitochondrial and extracellular matrix genes in the heart of human fetuses with chromosome 21 trisomy. BMC Genomics 2007, 8:268.

14. Lockstone HE, Harris LW, Swatton JE, Wayland MT, Holland AJ, Bahn S: Gene expression profiling in the adult Down syndrome brain. Genomics 2007, 90:647-60.

15. Rozovski U, Jonish-Grossman A, Bar-Shira A, Ochshorn Y, Goldstein M, Yaron $Y$ : Genome-wide expression analysis of cultured trophoblast with trisomy 21 karyotype. Hum Reprod 2007, 22:2538-45.

16. Cheung VG, Jen KY, Weber T, Morley M, Devlin JL, Ewens KG, Spielman RS: Genetics of quantitative variation in human gene expression. Cold Spring Harb Symp Quant Biol 2003, 68:403-7.

17. Monks SA, Leonardson A, Zhu H, Cundiff P, Pietrusiak P, Edwards S, Phillips JW, Sachs A, Schadt EE: Genetic inheritance of gene expression in human cell lines. Am J Hum Genet 2004, 75:1094-105.

18. Storey JD, Madeoy J, Strout JL, Wurfel M, Ronald J, Akey JM: Geneexpression variation within and among human populations. Am J Hum Genet 2007, 80:502-9.

19. Stranger BE, Forrest MS, Clark AG, Minichiello MJ, Deutsch S, Lyle R, Hunt S, Kahl B, Antonarakis SE, Tavaré S, Deloukas P, Dermitzakis ET: Genome-wide associations of gene expression variation in humans. PLoS Genet 2005, 1:e78.

20. Deutsch $\mathrm{S}$, Lyle R, Dermitzakis ET, Attar $\mathrm{H}$, Subrahmanyan L, Gehrig C, Parand L, Gagnebin M, Rougemont J, Jongeneel CV, Antonarakis SE: Gene expression variation and expression quantitative trait mapping of human chromosome 21 genes. Hum Mol Genet 2005, 14:3741-3749.

21. Prandini P, Deutsch S, Lyle R, Gagnebin M, Delucinge Vivier C, Delorenzi M, Gehrig C, Descombes P, Sherman S, Dagna Bricarelli F, Baldo C, Novelli A, Dallapiccola B, Antonarakis SE: Natural gene-expression variation in Down syndrome modulates the outcome of gene-dosage imbalance. Am J Hum Genet 2007, 81:252-263.

22. Sultan M, Piccini I, Balzereit D, Herwig R, Saran NG, Lehrach H, Reeves RH, Yaspo ML: Gene expression variation in Down's syndrome mice allows prioritization of candidate genes. Genome Biol 2007, 8:R91.

23. Ait Yahya-Graison E, Aubert J, Dauphinot L, Rivals I, Prieur M, Golfier G, Rossier J, Personnaz L, Creau N, Bléhaut H, Robin S, Delabar JM, Potier MC: Classification of human chromosome 21 gene-expression variations in 
Down syndrome: impact on disease phenotypes. Am J Hum Genet 2007, 81:475-9.

24. Sommer CA, Pavarino-Bertelli EC, Goloni-Bertollo EM, Henrique-Silva F: Identification of dysregulated genes in lymphocytes from children with Down syndrome. Genome 2008, 51:19-29.

25. Costa V, Sommese L, Casamassimi A, Colicchio R, Angelini C, Marchesano V, Milone L, Farzati B, Giovane A, Fiorito C, Rienzo M, Picardi M, Avallone B, Marco Corsi M, Sarubbi B, Calabrò R, Salvatore P, Ciccodicola A, Napoli C: Impairment of circulating endothelial progenitors in Down syndrome. BMC Med Genomics 2010, 3:40.

26. De Cegli R, Romito A, lacobacci S, Mao L, Lauria M, Fedele AO, Klose J, Borel C, Descombes P, Antonarakis SE, di Bernardo D, Banfi S, Ballabio A, Cobellis G: A mouse embryonic stem cell bank for inducible overexpression of human chromosome 21 genes. Genome Biol 2010, 1:R64.

27. Vilardell M, Rasche A, Thormann A, Maschke-Dutz E, Pérez-Jurado LA, Lehrach $\mathrm{H}$ : Meta-analysis of heterogeneous Down Syndrome data reveals consistent genome-wide dosage effects related to neurological processes. BMC Genomics 2011, 12:229.

28. Arron JR, Winslow MM, Polleri A, Chang CP, Wu H, Gao X, Neilson JR, Chen L, Heit JJ, Kim SK, Yamasaki N, Miyakawa T, Francke U, Graef IA, Crabtree GR: NFAT dysregulation by increased dosage of DSCR1 and DYRK1A on chromosome 21. Nature 2006, 441:595-600.

29. Lee EJ, Lee JY, Seo SR, Chung KC: Overexpression of DSCR1 blocks zinc-induced neuronal cell death through the formation of nuclear aggregates. Mol Cell Neurosci 2007, 35:585-95.

30. Kim YS, Cho KO, Lee HJ, Kim SY, Sato Y, Cho YJ: Down syndrome candidate region 1 increases the stability of the IkappaBalpha protein: implications for its anti-inflammatory effects. J Bio/ Chem 2006, 281:39051-61.

31. Ryoo SR, Cho HJ, Lee HW, Jeong HK, Radnaabazar C, Kim YS, Kim MJ, Son MY, Seo H, Chung SH, Song WJ: Dual-specificity tyrosine (Y)-phosphorylation regulated kinase $1 \mathrm{~A}$-mediated phosphorylation of amyloid precursor protein: evidence for a functional link between Down syndrome and Alzheimer's disease. J Neurochem 2008, 104:1333-44.

32. Canzonetta C, Mulligan C, Deutsch S, Ruf S, O'Doherty A, Lyle R, Borel C, Lin-Marq N, Delom F, Groet J, Schnappauf F, De Vita S, Averill S, Priestley JV, Martin JE, Shipley J, Denyer G, Epstein CJ, Fillat C, Estivill X, Tybulewicz VL, Fisher EM, Antonarakis SE, Nizetic D: DYRK1A-dosage imbalance perturbs NRSF/REST levels, deregulating pluripotency and embryonic stem cell fate in Down syndrome. Am J Hum Genet 2008, 83:388-400.

33. Porta S, Serra SA, Huch M, Valverde MA, Llorens F, Estivill X, Arbonés ML, Martí E: RCAN1 (DSCR1) increases neuronal susceptibility to oxidative stress: a potential pathogenic process in neurodegeneration. Hum Mol Genet 2007, 16:1039-50.

34. Valenti D, Tullo A, Caratozzolo MF, Merafina RS, Scartezzini P, Marra E, Vacca RA: Impairment of F1F0-ATPase, adenine nucleotide translocator and adenylate kinase causes mitochondrial energy deficit in human skin fibroblasts with chromosome 21 trisomy. Biochem J 2010, 431:299-310.

35. Valenti D, Manente GA, Moro L, Marra E, Vacca RA: Deficit of complex I activity in human skin fibroblasts with chromosome 21 trisomy and overproduction of reactive oxygen species by mitochondria: involvement of the CAMP/PKA signalling pathway. Biochem J 2011, 435:679-88.

36. Infantino V, Castegna A, lacobazzi F, Spera I, Scala I, Andria G, lacobazzi V: Impairment of methyl cycle affects mitochondrial methyl availability and glutathione level in Down's syndrome. Mol Genet Metab 2011, 102:378-82.

37. Pallardó FV, Lloret A, Lebel M, d'Ischia M, Cogger VC, Le Couteur DG, Gadaleta MN, Castello G, Pagano G: Mitochondrial dysfunction in some oxidative stress-related genetic diseases: Ataxia-Telangiectasia, Down Syndrome, Fanconi Anaemia and Werner Syndrome. Biogerontology 2010, 11:401-419.

38. Tlili A, Hoischen A, Ripoll C, Benabou E, Badel A, Ronan A, Touraine R, Grattau Y, Stora S, van Bon B, de Vries B, Menten B, Bockaert N, Gecz J, Antonarakis SE, Campion D, Potier MC, Bléhaut H, Delabar JM, Janel N: BDNF and DYRK1A Are Variable and Inversely Correlated in Lymphoblastoid Cell Lines from Down Syndrome Patients. Mol Neurobiol 2012, 46:297-303.

39. Jen KY, Cheung VG: Transcriptional response of lymphoblastoid cells to ionizing radiation. Genome Res 2003, 13:2092-100.

40. Islaih M, Li B, Kadura IA, Reid-Hubbard JL, Deahl JT, Altizer JL, Watson DE, Newton RK: Comparison of gene expression changes induced in mouse and human cells treated with direct-acting mutagens. Environ $\mathrm{Mol}$ Mutagen 2004, 44:401-19.

41. Rieger KE, Chu G: Portrait of transcriptional responses to ultraviolet and ionizing radiation in human cells. Nucleic Acids Res 2004, 32:4786-803.
42. Tsai HF, Lin SJ, Li C, Hsieh M: Decreased expression of Hsp27 and Hsp70 in transformed lymphoblastoid cells from patients with spinocerebellar ataxia type 7. Biochem Biophys Res Commun 2005, 334:1279-86.

43. Ballestar E, Ropero S, Alaminos M, Armstrong J, Setien F, Agrelo R, Fraga MF, Herranz M, Avila S, Pineda M, Monros E, Esteller M: The impact of MECP2 mutations in the expression patterns of Rett syndrome patients. Hum Genet 2005, 116:91-104.

44. Lee EJ, Seo SR, Um JW, Park J, Oh Y, Chung KC: NF-kappaB-inducing kinase phosphorylates and blocks the degradation of Down syndrome candidate region 1. J Biol Chem 2008, 283:3392-400.

45. Liu H, Wang P, Song W, Sun X: Degradation of regulator of calcineurin 1 (RCAN1) is mediated by both chaperone-mediated autophagy and ubiquitin proteasome pathways. FASEB J 2009, 23:3383-92.

46. Sugimoto $M$, Tahara $H$, Ide S, Furuichi $Y$ : Steps Involved in Immortalization and Tumorigenesis in Human B-Lymphoblastoid Cell Lines Transformed by Epstein-Barr Virus. Cancer Res 2004, 64:3361-3364.

47. Chen Z, Hagler J, Palombella VJ, Melandri F, Scherer D, Ballard D, Maniatis T: Signal-induced site-specific phosphorylation targets I kappa B alpha to the ubiquitin-proteasome pathway. Genes Dev 1995, 9:1586-97.

48. Wu CJ, Fu Y, Murali TM, Kasif S: Gene expression module discovery using gibbs sampling. Genome Inform 2004, 5:239-48.

49. Bassett DE Jr, Eisen MB, Boguski MS: Gene expression informatics-it's all in your mine. Nat Genet 1999, 1(Suppl 1):51-5.

50. Dennis G Jr, Sherman BT, Hosack DA, Yang J, Gao W, Lane HC, Lempicki RA: DAVID: Database for Annotation, Visualization, and Integrated Discovery. Genome Biol 2003, 4:P3

51. Zhang B, Schmoyer D, Kirov S, Snoddy J: GOTree Machine (GOTM): a web-based platform for interpreting sets of interesting genes using Gene Ontology hierarchies. BMC Bioinforma 2004, 5:16.

52. Lamb J, Crawford ED, Peck D, Modell JW, Blat IC, Wrobel MJ, Lerner J, Brunet JP, Subramanian A, Ross KN, Reich M, Hieronymus $H$, Wei G, Armstrong SA, Haggarty SJ, Clemons PA, Wei R, Carr SA, Lander ES, Golub TR: The Connectivity Map: using gene-expression signatures to connect small molecules, genes, and disease. Science 2006, 313:1929-35.

53. Filimonov DA, Poroikov W: Probabilistic approach in activity prediction. In Chemoinformatics Approaches to Virtual Screening. Edited by Alexandre V, Alexander T. Cambridge (UK): RSC Publishing; 2008:182-216.

54. Lagunin A, Filimonov D, Poroikov V: Multi-targeted natural products evaluation based on biological activity prediction with PASS. Curr Pharm Des 2010, 16:1703-17.

55. Radonić A, Thulke S, Mackay IM, Landt O, Siegert W, Nitsche A: Guideline to reference gene selection for quantitative real-time PCR. Biochem Biophys Res Commun 2004, 313:856-62.

56. de Brouwer $\mathrm{AP}$, van Bokhoven $\mathrm{H}$, Kremer $\mathrm{H}$ : Comparison of 12 reference genes for normalization of gene expression levels in Epstein-Barr virus-transformed lymphoblastoid cell lines and fibroblasts. Mol Diagn Ther 2006, 10:197-204.

57. Mimnaugh and Neckers: Immunoblotting Methods for the Study of Protein Ubiquitination. In Posttranslational Modifications of Proteins: Tools for Functional Proteomics. Volume 194. Edited by Kannicht C. Totowa, NJ: Humana Press Inc; 2002:179-203.

58. Galletti P, De Bonis ML, Sorrentino A, Raimo M, D'Angelo S, Scala I, Andria G, D'Aniello A, Ingrosso D, Zappia V: Accumulation of altered aspartyl residues in erythrocyte proteins from patients with Down's syndrome. FEBS J 2007, 274:5263-77

59. Sie L, Loong S, Tan EK: Utility of lymphoblastoid cell lines. J Neurosci Res 2009, 87:1953-9.

60. Tan EK, Sie L, Loong S: Growth rate from patient-derived lymphoblastoid cells with LRRK2 mutations. Mol Genet Metab 2008, 95:113.

61. Lin $\mathrm{CH}$, Tzen $\mathrm{KY}$, Yu CY, Tai CH, Farrer MJ, Wu RM: LRRK2 mutation in familial Parkinson's disease in a Taiwanese population: clinical, PET, and functional studies. J Biomed Sci 2008, 5:661-666.

62. Abe K, St George-Hyslop PH, Tanzi RE, Kogure K: Induction of amyloid precursor protein mRNA after heat shock in cultured human lymphoblastoid cells. Neurosci Lett 1991, 125:169-171.

63. Cao Y, Espinola JA, Fossale E, Massey AC, Cuervo AM, MacDonald ME, Cotman SL: Autophagy is disrupted in a knock-in mouse model of juvenile neuronal ceroid lipofuscinosis. J Biol Chem 2006, 281:20483-93

64. Merla G, Howald C, Henrichsen CN, Lyle R, Wyss C, Zabot MT, Antonarakis SE, Reymond A: Submicroscopic deletion in patients with Williams-Beuren 
syndrome influences expression levels of the nonhemizygous flanking genes. Am J Hum Genet 2006, 79:332-41.

65. Patterson D: Genetic mechanisms involved in the phenotype of Down syndrome. Ment Retard Dev Disabil Res Rev 2007, 13:199-206.

66. Kim SH, Vlkolinsky R, Cairns N, Lubec G: Decreased levels of complex III core protein 1 and complex $V$ beta chain in brains from patients with Alzheimer's disease and Down syndrome. Cell Mol Life Sci 2000, 57:1810-6.

67. Kim SH, Fountoulakis M, Dierssen M, Lubec G: Decreased protein levels of complex I 30-kDa subunit in fetal Down syndrome brains. J Neural Transm Suppl 2001, 61:109-16.

68. Lee SH, Lee S, Jun HS, Jeong HJ, Cha WT, Cho YS, Kim JH, Ku SY, Cha KY: Expression of the mitochondrial ATPase6 gene and Tfam in Down syndrome. Mol Cells 2003, 15:181-5.

69. Bajo M, Fruehauf J, Kim SH, Fountoulakis M, Lubec G: Proteomic evaluation of intermediary metabolism enzyme proteins in fetal Down's syndrome cerebral cortex. Proteomics 2002, 2:1539-46.

70. Druzhyna N, Nair RG, LeDoux SP, Wilson GL: Defective repair of oxidative damage in mitochondrial DNA in Down's syndrome. Mutat Res 1998, 409:81-9.

71. Bambrick LL, Fiskum G: Mitochondrial dysfunction in mouse trisomy 16 brain. Brain Res 2008, 1188:9-16.

72. Busciglio J, Pelsman A, Wong C, Pigino G, Yuan M, Mori H, Yankner BA: Altered metabolism of the amyloid beta precursor protein is associated with mitochondrial dysfunction in Down's syndrome. Neuron 2002, 28:677-88.

73. Raha S, Robinson BH: Mitochondria, oxygen free radicals, disease and ageing. Trends Biochem Sci 2000, 25:502-8.

74. Schon EA, Manfredi G: Neuronal degeneration and mitochondrial dysfunction. J Clin Invest 2003, 111:303-12.

75. Ames BN, Liu: Delaying the mitochondrial decay of aging with acetylcarnitine. Ann N Y Acad Sci 2004, 1033:108-116.

76. Kidd PM: Neurodegeneration from mitochondrial insufficiency: nutrients, stem cells, growth factors, and prospects for brain rebuilding using integrative management. Altern Med Rev 2005, 10:268-93.

77. Gandhi S, Wood NW: Molecular pathogenesis of Parkinson's disease. Hum Mol Genet 2005, 14:2749-2755.

78. Slonim DK, Koide K, Johnson KL, Tantravahi U, Cowan JM, Jarrah Z, Bianchi DW: Functional genomic analysis of amniotic fluid cell-free mRNA suggests that oxidative stress is significant in Down syndrome fetuses. Proc Natl Acad Sci USA 2009, 106:9425-9.

79. Costa V, Angelini C, D'Apice L, Mutarelli M, Casamassimi A, Sommese L, Gallo MA, Aprile M, Esposito R, Leone L, Donizetti A, Crispi S, Rienzo M, Sarubbi B, Calabrò R, Picardi M, Salvatore P, Infante T, De Berardinis P, Napoli C, Ciccodicola A: Massive-scale RNA-Seq analysis of non ribosomal transcriptome in human trisomy 21. PLoS One 2011, 6:e18493.

80. Ciechanover A: Intracellular protein degradation: from a vague idea thru the lysosome and the ubiquitin-proteasome system and onto human diseases and drug targeting. Cell Death Differ 2005, 12:1178-90.

81. Ding Q, Dimayuga E, Markesbery WR, Keller JN: Proteasome inhibition induces reversible impairments in protein synthesis. FASEB J 2006, 20:1055-63.

82. Van Tijn P, Hol EM, van Leeuwen FW, Fischer DF: The neuronal ubiquitinproteasome system: murine models and their neurological phenotype. Prog Neurobiol 2008, 85:176-93

83. Huang $\mathrm{Q}$, Figueiredo-Pereira ME: Ubiquitin/proteasome pathway impairment in neurodegeneration: therapeutic implications. Apoptosis 2010, 15:1292-311.

84. Lehman NL: The ubiquitin proteasome system in neuropathology. Acta Neuropathol 2009, 118:329-47.

85. Rogers N, Paine S, Bedford L, Layfield R: Review: the ubiquitin-proteasome system: contributions to cell death or survival in neurodegeneration. Neuropathol Appl Neurobiol 2010, 36:113-24.

86. Engidawork E, Juranville JF, Fountoulakis M, Dierssen M, Lubec G: Selective upregulation of the ubiquitin-proteasome proteolytic pathway proteins, proteasome zeta chain and isopeptidase T in fetal Down syndrome. J Neural Transm Suppl 2001, 61:117-30.

87. Necchi D, Lomoio S, Scherini E: Dysfunction of the ubiquitin-proteasome system in the cerebellum of aging Ts65Dn mice. Exp Neurol 2011, 232:114-8.

88. Choi JH, Berger JD, Mazzella MJ, Morales-Corraliza J, Cataldo AM, Nixon RA, Ginsberg SD, Levy E, Mathews PM: Age-dependent dysregulation of brain amyloid precursor protein in the Ts65Dn Down syndromemouse model. J Neurochem 2009, 110:1818-27.

89. Busciglio J, Yankner BA: Apoptosis and increased generation of reactive oxygen species in Down's syndrome neurons in vitro. Nature 1995, 378:776-9.
90. Pagano G, Castello G: Oxidative stress and mitochondrial dysfunction in Down syndrome. Adv Exp Med Biol 2012, 724:291-9.

91. Zana M, Janka Z, Kálmán J: Oxidative stress: a bridge between Down's syndrome and Alzheimer's disease. Neurobiol Aging 2007, 28:648-76.

92. Peled-Kamar M, Lotem J, Okon E, Sachs L, Groner Y: Thymic abnormalities and enhanced apoptosis of thymocytes and bone marrow cells in transgenic mice overexpressing $\mathrm{Cu} / \mathrm{Zn}$-superoxide dismutase: implications for Down syndrome. EMBO J 1995, 14:4985-93.

93. Liu LJ, Liu TT, Ran Y, Li Y, Zhang XD, Shu HB, Wang YY: The E3 ubiquitin ligase MIB1 negatively regulates basal IKBa level and modulates NF-KB activation. Cell Res 2012, 22:603-6.

94. Kanarek N, Ben-Neriah Y: Regulation of NF-kB by ubiquitination and degradation of the IKBs. Immunol Rev 2012, 246:77-94.

95. Oeckinghaus A, Hayden MS, Ghosh S: Crosstalk in NF-KB signaling pathways. Nat Immunol 2011, 12:695-708.

96. Stankunas K, Graef IA, Neilson JR, Park SH, Crabtree GR: Signaling through calcium, calcineurin, and NF-AT in lymphocyte activation and development. Cold Spring Harb Symp Quant Biol 1999, 64:505-16.

97. Beals CR, Clipstone NA, Ho SN, Crabtree GR: Nuclear localization of NF-ATc by a calcineurin-dependent, cyclosporin-sensitive intramolecular interaction. Genes Dev 1997, 11:824-34.

98. Butterfield DA, Drake J, Pocernich C, Castegna A: Evidence of oxidative damage in Alzheimer's disease brain: central role for amyloid beta-peptide. Trends Mol Med 2001, 7:548-54.

99. Lott IT, Head E, Doran E, Busciglio J: Beta-amyloid, oxidative stress and Down syndrome. Curr Alzheimer Res 2006, 3:521-528.

100. Yang H, Zonder JA, Dou QP: Clinical development of novel proteasome inhibitors for cancer treatment. Expert Opin Investig Drugs 2009, 18:957-e971.

101. Adams J: Potential for proteasome inhibition in the treatment of cancer. Drug Discov Today 2003, 8:307-15.

102. Zavrski I, Naujokat C, Niemöller K, Jakob C, Heider U, Langelotz C, Fleissner C, Eucker J, Possinger K, Sezer O: Proteasome inhibitors induce growth inhibition and apoptosis in myeloma cell lines and in human bone marrow myeloma cells irrespective of chromosome 13 deletion. J Cancer Res Clin Oncol 2003, 129:383-91.

103. Beg AA, Baltimore D: An essential role for NF-kB in preventing TNF-a-induced cell death. Science 1996, 274:782-784

104. Van Antwerp DJ, Martin SJ, Kafri T, Green DR, Verma IM: Suppression of TNF-a-induced apoptosis by NF-KB. Science 1996, 274:787-789.

105. Wang CY, Mayo MW, Baldwin AS: TNF- and cancer therapy-induced apoptosis: potentiation by inhibition of NF-KB. Science 1996, 274:784-787.

106. Bogani P, Galli C, Villa M, Visioli F: Postprandial anti-inflammatory and antioxidant effects of extra virgin olive oil. Atherosclerosis 2007, 190:181-6.

107. Koh SH, Kwon H, Kim KS, Kim J, Kim MH, Yu HJ, Kim M, Lee KW, Do BR, Jung HK, Yang KW, Appel SH, Kim SH: Epigallocatechin gallate prevents oxidative-stress-induced death of mutant $\mathrm{Cu} / \mathrm{Zn}$-superoxide dismutase (G93A) motoneuron cells by alteration of cell survival and death signals. Toxicology 2004, 202:213-25.

108. Schroeder EK, Kelsey NA, Doyle J, Breed E, Bouchard RJ, Loucks FA, Harbison RA, Linseman DA: Green tea epigallocatechin 3-gallate accumulates in mitochondria and displays a selective antiapoptotic effect against inducers of mitochondrial oxidative stress in neurons. Antioxid Redox Signal 2009, 11:469-80.

109. Nam S, Smith DM, Dou QP: Ester bond-containing tea polyphenols potently inhibit proteasome activity in vitro and in vivo. $J$ Biol Chem 2001, 276:13322-30.

110. Khan N, Adhami VM, Mukhtar H: Apoptosis by dietary agents for prevention and treatment of prostate cancer. Endocr Relat Cancer 2010, 17:R39-52.

111. Bain J, McLauchlan H, Elliott M, Cohen P: The specificities of protein kinase inhibitors: an update. Biochem J 2003, 371:199-204.

112. Guedj F, Sébrié C, Rivals I, Ledru A, Paly E, Bizot JC, Smith D, Rubin E, Gillet B, Arbones M, Delabar JM: Green Tea Polyphenols Rescue of Brain Defects Induced by Overexpression of DYRK1A. PLoS One 2009, 4:e4606.

doi:10.1186/1755-8794-6-24

Cite this article as: Granese et al: Validation of microarray data in human lymphoblasts shows a role of the ubiquitin-proteasome system and NF-kB in the pathogenesis of Down syndrome. BMC Medical Genomics 2013 6:24. 